\title{
Sustainability of Microfinance Self Help Groups in India: Would Federating Help?
}

\author{
Ajai Nair \\ Consultant, World Bank \\ Email: anair@worldbank.org
}

\begin{abstract}
World Bank Policy Research Working Paper 3516, February 2005
The Policy Research Working Paper Series disseminates the findings of work in progress to encourage the exchange of ideas about development issues. An objective of the series is to get the findings out quickly, even if the presentations are less than fully polished. The papers carry the names of the authors and should be cited accordingly. The findings, interpretations, and conclusions expressed in this paper are entirely those of the authors. They do not necessarily represent the view of the World Bank, its Executive Directors, or the countries they represent. Policy Research Working Papers are available online at http://econ.worldbank.org.
\end{abstract}

This paper was prepared for the South Asia Region, Finance and Private Sector Development Unit of the World Bank. The guidance received from Marilou Uy, Sector Director of the Unit at the time the paper was commissioned, is gratefully acknowledged. Sophie Sirtaine, then Financial Specialist in the Unit, helped design the study and reviewed the initial drafts. Helpful comments were provided by Maya Tudor and Kathryn Gwatkin, then graduate students at the Woodrow Wilson School. The revised paper was reviewed by Priya Basu, Senior Financial Economist and Niraj Verma, Financial Specialist. The time contributed by staff and leaders of organizations visited and other individuals interviewed, and comments of participants at various fora at which the initial drafts were presented, are also gratefully acknowledged.

Initial fieldwork for this paper was done in July 2001 when the author was a graduate student at the Woodrow Wilson School of Public and International Affairs, Princeton University. A draft version of the paper was presented at the workshop on microfinance organized jointly by the World Bank and NABARD at New Delhi in September 2002. The paper was revised and updated in July 2003. 


\begin{abstract}
The major form of microfinance in India is that based on women's Self Help Groups (SHGs), which are small groups of 10-20 members. These groups collect savings from their members and provide loans to them. However, unlike most Accumulating Savings and Credit Associations (ASCAs) found in several countries, these groups also obtain loans from banks and on-lend them to their members. By 2003, over 700,000 groups had obtained over Rs.20 billion (US\$425 million) in loans from banks benefiting more than 10 million people. Delinquencies on these loans are reported to be less than $5 \%$. Savings in these groups is estimated to be at least Rs.8 billion (US $\$ 170$ million). Despite these considerable achievements, sustainability of the SHGs has been suspect because several essential services required by the SHGs are provided free or at a significantly subsidized cost by organizations that have developed these groups. A few promoter organizations have, however, developed federations of SHGs that provide these services to the SHGs and others that SHG members need, but which SHGs cannot feasibly provide. Using a case study approach, this paper explores the merits and constraints of federating. Three SHG federations that provide a wide range of services are studied. The findings suggest that federations could help SHGs become institutionally and financially sustainable because they provide the economies of scale that reduce transaction costs and make the provision of these services viable. However, their sustainability is constrained by several factors - both internal, related to the federations themselves and external, related to the other stakeholders. The paper concludes by recommending some actions to address these constraints.
\end{abstract}




\section{Introduction}

The term Self Help Groups (SHGs) is generally used in India to refer to unregistered groups of 10 to 20 members involved primarily in savings and credit activities. As in the case of the typical Accumulating Savings and Credit Associations (ASCAs) described by Bowman (1995), the members save periodically in the group and the savings are lent out to members who require loans at a fixed rate of interest. SHGs however differ from typical ASCAs in their small size, their being promoted ${ }^{1}$ among the poor by external agencies, and most importantly in their obtaining loans from banks. Over 90 percent of these groups have only women members. Tankha (2002) provides an overview of microfinance SHGs in India.

Over the last decade, cumulatively more than 700,000 SHGs have obtained approximately Rs. 20 billion (US $\$ 425$ million) in loans from banks under a program of the National Bank of Agriculture and Rural Development (NABARD). Since the average membership of SHGs is around 15, in cumulative terms over 10 million people may have thus benefited from such loans. The on-time repayment rate on these loans has been over 95 percent. In addition to the NABARD program, several other financial institutions ${ }^{2}$ lend to NGOs for on-lending to SHGs. By a conservative estimate, savings in SHGs are at least Rs. 8 billion (US $\$ 170$ million). ${ }^{3}$

However, despite its considerable outreach, successful savings mobilization, and high loan-repayment rates, the sustainability of SHG banking has not been clear. The small size of the SHGs and thereby, the limited resources - both financial and human - they have access to, make most SHGs dependent on the promoter agencies for several essential services. SHG federations were primarily a response to this issue; they were promoted to take over most, or all, of the services for which the SHGs were dependent on the promoter agencies.

This study explores the potential of SHG federations in providing sustainability to SHGs. SHG federations studied here provide a wide variety of services including financial services. These federations are more difficult to manage and govern than other federations that provide a narrower range of services; they are also more difficult to develop. However, federations of the type studied here provide the broadest range of services of significant value to the SHGs. The sample of federations studied also represents best cases, rather than a representative sample of SHG federations in existence. Hence, the findings of the study

\footnotetext{
${ }^{1}$ Process of supporting through financial and non-financial means their formation and development. The words promotional cost and promoter agencies are also used in this context.

${ }^{2}$ Small Industries Development Bank of India, Housing and Urban Development Corporation, Rashtriya Mahila Kosh, and Federation of World Women's Banking.

${ }^{3}$ NABARD guidelines for its SHG-Bank linkage program recommends that banks start lending with a ratio of 1:1 or 1: 2 (savings to loans). First-time loans continue to be the major portion of bank loans; in 2001-02, loans to new SHGs formed 83 percent of all bank loans (and the same proportion in loan amount), in 2002-03 proportion of new loans was 71 percent and proportion of loan amount 68 percent. In earlier years, the proportion of new loans is likely to have been much higher. Assuming conservatively 80 percent of cumulative lending under the program to be first time loans and that all first time loans had a savings to loan ratio of 1: 2, consolidated savings in all SHGs that have obtained loans under the program should be at least Rs. 8 billion.
} 
only indicate the potential of SHG federations and do not reflect the performance of an average SHG federation.

The report is laid out as follows: the remaining part of this section gives an overview of the SHG-Bank linkage program, other member-based microfinance organizations in India, federations of member-based organizations in general, and SHG federations. Section 2 spells out the objectives of the study, explains the scope, and gives brief profiles of the federations studied. Section 3 describes the services provided by the primary organizations and the federations. Section 4 analyzes the benefits of federating and Section 5 presents the results of financial analysis conducted for two federations. Sections 6 and 7 identify issues and challenges related to the sustainability and promotion of SHG federations. Finally, Section 8 summarizes the findings of the study and discusses the implications.

\section{SHG-Bank Linkage Program}

This program, developed and managed by NABARD, allows SHGs to obtain loans from banks - commercial, rural, and cooperative banks. The banks lend to the SHGs and are eligible for NABARD refinance for these loans at a subsidized interest rate. The program's main claim to success has been the significant outreach achieved and repayment rates of over $95 \%$ (compared to other poverty lending programs that have had repayment rates of less than 50\%). As of March 2003, over 700,000 SHGs had received a total of over Rs.20 billion (US $\$ 425$ million) in loans from over 500 banks (NABARD website). Kropp and Suran (2002) provide an overview of the evolution and achievements of the program over the last 10 years.

The program, started in 1992 as a pilot project and upgraded to a regular banking program in 1996, has expanded rapidly since then. NABARD's refinance has however been falling in proportion - possibly because of the prevailing low interest rates, high level of liquidity in banks, and not the least, because of the banks starting to see the program as a profitable proposition. Of the Rs.10.2 billion (US $\$ 212$ million) lent by banks in 2002-03, they only requested Rs.6.2 billion (US\$130 million) in refinance (NABARD, 2003). NABARD's original goal of supporting one million SHGs under this program by 2008 seems easily surpassable. A Microfinance Development Fund, created at NABARD with a start up fund of Rs.1 billion (US\$21 million) using contributions from the Reserve Bank of India, NABARD and other commercial banks, is to be used to consolidate and further expand the program.

The growth of the program was slow during the initial years for several reasons. Unlike other subsidized lending programs supported by the government, the program is not mandatory for the banks. Involvement of multiple actors - promoter organizations to form the SHGs, the SHGs themselves, and banks - meant a naturally slow institutional learning process. There was also a paucity of capable promoter organizations and insufficient funds for SHG promotion. Most importantly, the lending methodology was novel for the banks. In contrast to the individual and activity based lending that the bankers were familiar with, SHG-lending is organization-based. Adherence to organizational practices such as proper maintenance of accounts, regular group meetings, and good loan-repayment performance on 
internal lending were to be used to determinants of creditworthiness. Banks were also hesitant to lend to SHGs because the loans were required to be collateral-free.

Several factors explain the rapid increase in program outreach in recent years. Apart from natural learning process of all actors involved, NABARD's extensive training programs to all the actors involved played a significant role; it has organized or financed over 2000 programs for bankers and over 250 programs for NGOs and government functionaries (NABARD website). The adoption by the central government of the SHG concept as its primary anti-poverty self-employment program (the Swarnajayanthi Gram Swarozgar Yojana - SGSY) also aided program growth though the sustainability and average quality of SHGs promoted under this program is debatable. ${ }^{4}$ Finally, Andhra Pradesh state made SHGs their flagship strategy in rural development resulting in various government agencies forming SHGs.

Nevertheless, the program faces several challenges. Most critical is the issue of sustainability of the SHGs; many are dependent on the promoter organizations for even routine tasks such as maintenance of account books and conducting of meetings where transactions take place. Others operate at a low equilibrium of low savings and low credit that is unlikely to contribute significantly to improving the lives of SHG members. Most importantly, for the financial year ending March 31, 2003, only 102,391 SHGs obtained repeat bank loans. Repeat loans are critical because it indicates that loans to SHGs are not one-time loans as in the case of traditional subsidized loans, but that the banks could be a dependable source of loans for the SHGs. It is only when the number of repeat loans become significant that SHG-based microfinance could be said to be on par with financial services provided by other well-performing Micro Finance Organizations (MFOs). The program also continues to be concentrated predominantly in South India. As of 2002, 78\% of total SHGs and $81 \%$ of the amount lent was in the four states in South India and $53 \%$ of total SHGs and $51 \%$ of the amount lent in the state of Andhra Pradesh alone (NABARD n.d.).

\section{Other Member-based Microfinance Organizations}

Thrift cooperatives are the major member-based microfinance organizations in India. However, they have traditionally been urban-based and typically formed among employees within an organization. State or federal laws regulate these cooperatives, and their performance often suffers due to excessive state control and political interference. Two

\footnotetext{
${ }^{4}$ SGSY replaced the Integrated Rural Development Program and other poverty eradication programs. Integrated Rural Development Program, the largest anti-poverty program implemented in India, was in place for two decades. The bank loans under the program, a major component, had a disastrous average repayment rate of less than $40 \%$. SGSY adopts the SHG concept of group and savings, but provides capital and interest subsidy for investment loans. Unlike the SHG-based microfinance program, SGSY lending by banks is mandatory. The major change in SGSY from that of Integrated Rural Development Program is that a significant portion of the funds - both loans and grants are to be made available to SHGs rather than individuals. SHGs are supported where they exist and new ones promoted where they do not. Furthermore, though SGSY envisages an increased role for Banks and NGOs, government-owned District Rural Development Agencies that lack the required capacity to administer such programs are the primary implementing agencies. Concerns on SGSY's potential negative impact on the SHG-bank linkage program have been raised on account of its targeted and subsidy driven approach though hopefully these will not have much impact as the SHG-bank linkage program is well established.
} 
significant exceptions to the rule have been the cooperatives promoted by two organizations: Cooperative Development Foundation and Working Women's Federation. All cooperatives promoted by Cooperative Development Foundation are in rural areas, while that promoted by Working Women's Federation are in both urban and rural areas.

Cooperative Development Foundation has promoted village-level cooperatives that are fully owned and managed by their members. As of 2002, 400 such cooperatives with 87,500 members and a consolidated loan portfolio Rs. 180 million (US $\$ 3.8$ million) were in operation. The thrift cooperative promoted by Working Women's Federation - Indian Cooperative Network for Women - has branches in the states of Tamil Nadu, Andhra Pradesh and Karnataka. As of March 2001, this cooperative had 98,184 members, Rs.11 million (US\$234,000) in savings, and a loan portfolio of Rs.54.75 million (US\$1.2 million).

The most well-known member-based microfinance organization is SEWA Bank, promoted by the Self Employed Women's Association (SEWA), a trade union of women working in the informal sector. As of 2001, SEWA Bank, an urban cooperative bank, had 25,464 shareholders and a working capital of Rs.390 million (US\$8.3 million) (SEWA website).

\section{An Overview of Federations}

A federation is an association of organizations. Organizations form federations to realize economies of scale and gain strength as an interest group while retaining the advantages of remaining autonomous. Federations of cooperatives have a long history. Credit unions have federated at national, regional, (e.g. Association of Asian Confederation of Credit Unions) and global (World Council of Credit Unions) levels. The World Council of Credit Unions represents 36,512 credit unions with a combined membership of 108 million, and they have more than US $\$ 466$ billion in savings and US $\$ 371$ billion in loans (World Council of Credit Unions website). Among national federations, Desjardins of Quebec, Canada is among the best known. The Desjardins national federation has 639 member cooperatives, which collectively have over five million members. As of December 2002, the group had over US $\$ 85$ billion in assets (Desjardins website). Federations of village banks in Africa are another documented case of federations among member-based organizations (Eschborn 1999).

In India, cooperative banking and marketing societies are federated at the district, state, and national levels. Excessive state regulation in the cooperative sector in India, however, leaves hardly any member control in these federations. Gujarat Cooperative Milk Marketing Federation (GCMMF), a federation of dairy cooperatives, is among the few exceptions. GCMMF is a three-tiered federation composed of 11,132 village-level primary societies (2.3 million members), 12 district-level federations, and a state-level confederation of the district federations. GCMMF produces the AMUL brand of products, which is market leader in processed dairy products in India and generated Rs.27 billion (US\$575) million in sales in 2002-03 (GCMMF website). The South Indian Federation of Fishermen Societies (SIFFS) is a well-functioning group of organizations in the fishery sector. The village societies had a turnover of over Rs.754 million (US\$16 million) in 2002 (SIFFS 
website). SIFFS is also a three-tiered federation with village-level societies, district level federations, and a confederation of district federations in three southern states. 


\section{SHG Federations}

SHG federations are different from the federations discussed above in several ways. The major difference is in the size of the primary organization; SHGs are much smaller than the dairy cooperatives, the fishermen societies, or the credit unions. Because of the small size and their membership being mostly or exclusively poor, SHGs also have smaller financial resources and more limited human capacity than other typical primary organizations that form federations. SHGs are also informal organizations i.e. they are not legally incorporated as in the case of the cooperatives or the fishermen societies.

SHG federations were promoted primarily as an exit strategy, i.e. to allow organizations that had promoted SHGs to withdraw their support to SHGs while also ensuring their sustainability. Professional Assistance for Development Action and Mysore Resettlement and Development Agency (MYRADA), two large NGOs that pioneered the concept of SHGs, were also among the earliest agencies to promote SHG federations. Development of Humane Action (DHAN) Foundation further refined the federation model promoted by Professional Assistance for Development Action. Other major NGOs that have promoted SHG federations include SEWA in Gujarat, PREM in Orissa, Chaitanya in Maharashtra, Gram Vikas in Karnataka, and YCO in Andhra Pradesh (FWWB 1997). The structure of the federations and the functions performed vary and depend significantly on the promoting NGO. However, the federations supported by DHAN and MYRADA represent two major models.

Federations promoted by DHAN usually have more than 200 SHGs as members, provide a wide range of services including financial services, and employ paid staff. The federation structure is a nested-structure with SHGs as members in cluster-level federations and block-level ${ }^{5}$ federations; the block-level is a registered entity, either as a society or trust. DHAN has promoted over 30 such federations. In contrast, federations promoted by MYRADA are unregistered associations of 15-25 SHGs each, do not have paid staff, and provide a more limited range of services that does not include financial services. ${ }^{6}$ The federation has no permanent staff, office, or funds. MYRADA had promoted over 50 such SHG federations by 2001.

Since 2001, MYRADA has promoted new organizations called Resource Centers that are similar in operational area and services offered to the block-level federations of SHGs promoted by DHAN. However, the membership in the Resource Centers is not restricted to SHGs; though the majority of the members are SHGs, Water Development Associations and other community-based organizations supported by MYRADA, are also members. As the name suggests, the Resource Centers are designed to serve as a resource for the services required by community-based organizations in an area. The Resource Centers are typically governed by executive committees with representatives from the SHGs, other member organizations, and MYRADA. The member organizations pay monthly

\footnotetext{
${ }^{5}$ Blocks are sub-district administrative units in India and are the lowest unit of development planning and implementation.

6 The MYRADA federations primarily focus on building solidarity, addressing delinquency, and dealing with social issues. Some of the federations offer audit services.
} 
contributions as well as service charges for specific services received. The major categories of services offered by the Resource Centers are facilitation of external audit, training, account maintenance, and facilitation of linkage with banks. Presently, MYRADA partially subsidizes the costs of the cost of the Resource Centers in the form of its staff time and infrastructure support, but expects them to become self-sufficient in due course (MYRADA n.d.).

Several government agencies are also promoting SHG federations. The Society for Elimination of Rural Poverty (SERP), an agency formed by the Andhra Pradesh government, is implementing two World Bank-supported projects - Andhra Pradesh District Poverty Initiatives Project and Andhra Pradesh Poverty Reduction Project. The major component of these projects supports existing SHGs, forms new SHGs, and federates them at the village and mandal level. ${ }^{7}$ These projects together expect to form over 500 mandal-level federations. These federations are similar in size and functions to the ones promoted by DHAN (World Bank 2000, 2003). These projects also provide investment funds to the federations to be lent to the SHGs. Other government agencies involved in promoting SHGs and SHG federations include Women Development Corporations in Maharashtra and Tamil Nadu. These federations are similar to SHG federations supported by MYRADA in size, structure, and functions.

Sa-dhan, a network on MFOs in India, recently studied 27 SHG federations. The federations were from all regions of India, with the majority (13) from the south. Nineteen federations provide financial services, while eight do not. Among the 19 providing financial services, only six have strong member control; others are primarily controlled by the promoter agency. The most common structure was a three-tier one, though both lesser and more levels of aggregation exist. The study concludes that federations involved in financial intermediation are likely to achieve sustainability while those involved only in social intermediation are unlikely to do so.

\section{Objectives, Methodology and Scope}

\section{Objectives}

The overall objective of the study is to explore the potential of SHG federations in making SHGs financially and organizationally sustainable, and to recommend strategies to strengthen them. The specific objectives were:

a) Identify the services provided by the federations and analyze their benefits to SHGs,

b) Assess the financial viability of SHGs and SHG federations, and estimate the cost of promoting them,

c) Identify the constraints in federating SHGs, and

d) Recommend strategies to strengthen SHG federations.

\footnotetext{
${ }^{7}$ Mandals are sub-district development unit unique to Andhra Pradesh. These are smaller in geographical size and population than blocks, the sub-district development units in all other states in India.
} 


\section{Methodology}

The federations to be studied were selected in two stages. In the first stage, organizations that have promoted federations were identified based on a literature review and the primary researcher's personal experience. From among these organizations, three organizations were selected purposively. Annex 4 provides a brief profile of the selected organizations. These organizations have promoted a significant number of federations with the following characteristics: the core activity of primary organizations is microfinance, the federations provide a wide range of services, and the federations are formal organizations that have their own board, staff and funds. In the second stage, the promoter organizations were asked to suggest the federations to be studied, subject to the condition that they have been in existence for at least three years. A thrift cooperative federation was included in the study sample to give a comparative perspective.

The organizational, financial, and program information on the federations was collected using a detailed questionnaire and from annual reports and financial statements of the federations. In addition, key informant and focus group interviews were conducted with representatives of the primary organizations, the federations, the promoter organizations, NABARD, commercial banks (ICICI Bank and Canara Bank), and other organizations working on other models of microfinance (Basix, WWF and MYRADA). Annex 5 gives the complete list of organizations visited and individuals interviewed. Annex 1 gives a detailed description of the methodology used for financial viability analysis. The study was conducted over a period of three months, including three weeks of fieldwork in India

\section{Scope}

The federations studied are best cases rather than representative cases, and are not typical of the average SHG federations in existence. However, this is in keeping with the objective of the study to explore the potential of SHG federations in making SHGs sustainable (and not that of assessing the overall performance of SHG federations). Annex 4 provides estimates of outreach and extent of services provided by SHGs and federations similar to the ones studied here. Brief profiles of the four federations studied are as follows:

Sri Padmavathy Mabila Abyudaya Sangam (SPMS): SPMS is a federation of SHGs in the famous temple town of Tirupati in Andhra Pradesh. Most SHGs that are members in SPMS are located in the slums in the town; some are located in the peri-urban areas. Promoted in 1992, it is one of the oldest SHG federations in India. The UNDP-World Bank Water and Sanitation Program has documented the achievements of the federation in providing infrastructure services to its members (UNDP-World Bank Water and Sanitation Program n.d.). DHAN Foundation currently supports SPMS by providing management professionals, strategic advice, and support for resource mobilization.

Kurinji Vattara Kalanjiam (KVK): KVK is a federation of SHGs in Alanganallur block, near Madurai, a southern city in the state of Tamil Nadu. Allanganallur is famous for its annual bullfights and dairying is a major livelihood in the area. SHGs in the area were promoted in 1995 and the federation was promoted in 1997. KVK is typical of the federations with a nested structure promoted by DHAN Foundation- all SHGs in a block 
are federated into a block- level federation (KVK), and SHGs in a cluster of villages form a cluster-level federation called a Cluster Development Association (CDA).

Sanghamitra Mandala Mabila Samakbya (SMMS): SMMS is located in the Hindupur mandal of Anantpur district in Andhra Pradesh. In contrast to the nested structure in KVK, SMMS has the more common three-tiered structure observed in federated organizations. The mandal federation is a federation of Village Organizations (VOs), and Village organizations are federations of SHGs. Anantpur is among the least developed regions in Andhra Pradesh. SHGs in the area were promoted in the area 1996, and the federation was started in1998. Society for Elimination of Rural Poverty (SERP) supports SMMS.

Sri Viswabharthi Association of Women Thrift Cooperatives (SVAWTC): SVAWTC, formed in 1991, is a federation of thrift cooperatives in Warangal District of Andhra Pradesh. The thrift cooperatives are village-level organizations and are hence larger than SHGs. The federation is one of the oldest women thrift cooperatives promoted by Cooperative Development Foundation (CDF).

In all the cases except SVAW'TC, membership is restricted to the poor, who are identified by Participatory Rural Appraisal techniques. ${ }^{8}$ Though the membership of SVAWTC is not exclusively poor, the majority of members are poor. A CDF study on the member profile of SVAWTC in 1997 found 44\% of members to be landless and $22 \%$ to hold less than 2 acres (CDF 1997). Land ownership is a good proxy for wealth in rural areas. The small size of the required general savings and the system of loan eligibility being a proportion of general savings (rather than total savings that may include other deposits), also make the cooperative unattractive to the rich. The thrift amount in most cooperatives is low enough (Rs.20 per month) for the poorest member to be able to save. Annex 2 gives a more detailed description of the structure and systems in the federations studied. Annex 4 gives the profiles of the promoter agencies of the federations studied.

\footnotetext{
${ }^{8}$ Participatory Rural Appraisal techniques are tools used to collect reliable information regarding a village, street, etc. by a process of consultation with area residents, often in a group. PRA tools require less time and cost compared with conventional survey methods.
} 
Table 1. Organizational Profiles of the Federations, 2000

\begin{tabular}{|c|c|c|c|c|}
\hline Particulars & SPMS & KVK & SMMS & SVAWTC \\
\hline \multicolumn{5}{|l|}{ Clientele } \\
\hline Members & 7272 & 3900 & 2699 & 4337 \\
\hline Primary Groups & 617 & 242 & 206 & 11 \\
\hline Average group membership & 12 & 16 & 13 & 394 \\
\hline \multicolumn{5}{|l|}{ Savings } \\
\hline Savings (Rupees million) & 21.1 & 9 & 3.5 & 8.1 \\
\hline Average Member Savings (Rupees) & 2902 & 2319 & 1296 & 1871 \\
\hline Savings (US\$) & 448,986 & 192,388 & 74,399 & 172,652 \\
\hline Average Member Savings (US\$) & 62 & 49 & 28 & 40 \\
\hline Nominal Interest on savings ( $\%)$ & 12 & 12 & None & 12 \\
\hline \multicolumn{5}{|l|}{ Loans (Rupees. Million) } \\
\hline External loans to date & 31.7 & 24.2 & 1.9 & None \\
\hline External grants for lending & 1.3 & 1.1 & 6.7 & None \\
\hline Total credit generated & 79.5 & 49.1 & 31.3 & n.a. \\
\hline Loan portfolio at primary & 39.7 & 23.3 & 12.2 & 11.6 \\
\hline Loan portfolio at apex level & 20 & 9.5 & 4.8 & 2.4 \\
\hline \multicolumn{5}{|l|}{ Loans (US\$) } \\
\hline External loans to date & 675,130 & 514,130 & 25,283 & None \\
\hline External grants for lending & 26,957 & 22,391 & 141,761 & None \\
\hline Total credit generated & $1,690,435$ & $1,043,696$ & 665,870 & n.a. \\
\hline Loan portfolio at primary & 844,573 & 495,471 & 260,065 & 246,522 \\
\hline Loan portfolio at apex level & 425,493 & 201,352 & 101,352 & 50,870 \\
\hline \multicolumn{5}{|l|}{ Staff and Infrastructure } \\
\hline Full time staff ${ }^{a}$ & 10 & 32 & 10 & 12 \\
\hline Office & Rented & Rented & Rented & Own \\
\hline
\end{tabular}

n.a Not Available

Notes: Year ending March 2001 for SPMS and KVK

a. Primary organizations and federations combined. 


\section{Services Offered by SHGs, Thrift Cooperatives, and their Federations}

Though the primary interest of this study is in the services offered by federations, information on the services offered by the primary groups is also presented in this section to better understand the full range of services available to members in the primary groups. Annex 3 gives a more detailed description of the functions performed by the federations.

\section{Primary Groups}

SHGs and thrift cooperatives primarily provide savings and loan facility to their members. Savings is at the core of the SHG model and particularly so for thrift cooperatives promoted by CDF because they do not receive external loan funds. Savings are retained in the primary groups; it is not pooled at the federation or deposited with the local banks. The major form of savings is the general savings. In the SHGs, all members have uniform general savings, while in others it varies between members. In the thrift cooperatives, the general savings - termed thrift - is uniform. In addition to the general savings, some members in SHGs in KVK and SPMS save periodically for a particular purpose such as housing, festival, education, marriage, etch. In thrift cooperatives, some members have fixed deposits. All primary groups except those in SMMS pay 12 percent annual interest on all savings. Members' monthly savings range from Rs.25 (US\$0.53) to Rs.250 (US\$5.30) per month.

The ability of the SHGs and thrift cooperatives to provide both small and relatively large loans at the time of need, at costs lower than those available in the local market, and without collateral or excessive documentation attract the poor to these organizations. In KVK, SPMS, and the thrift cooperative, interest rates on general loans range from 24 percent to 36 percent per annum, while in SMMS all loans have an interest rate of 24 percent. Housing loans in KVK are available to members at 15 percent, and in SPMS at 18 percent. KVK and SPMS permit a member to have up to three loans at the same time. In contrast, the other federations do not permit members to have more than one active loan at a time. Loans range from very small loans of Rs.100 (US\$2.13) to large housing loans of Rs.40000 (US\$851).

\section{Cluster Development Associations and Village Organizations}

Cluster Development Associations (CDAs) provide a wide range of services, the primary one being lending to SHGs. The apex federation is their principal source of funds, but they also have their own funds (equity from SHGs, grants from NGO and accumulated profit). Other services provided include training, accounts and auditing support, dissemination of information on new programs (initiated by the apex federations), and facilitation of SHG-bank linkage. CDAs also promote new SHGs.

Village Organizations (VOs) have fewer resources than the CDAs and provide a smaller range of services. They provide some general support to SHGs and basic health care and livestock care through trained volunteers. VO also provides a forum for all the SHGs in a village to discuss common issues and interact with village leaders. Since the CDAs have their own staff, they also work more autonomously than the VOs. 
Table 2. Services Offered by SHGs and Thrift Cooperatives

\begin{tabular}{|c|c|c|c|c|}
\hline Particulars & $S P M S$ & $K V K$ & $S M M S$ & $S V A W T C$ \\
\hline \multicolumn{5}{|l|}{ Savings } \\
\hline General savings & $\begin{array}{l}\text { Variable amounts, } \\
\text { withdrawals only } \\
\text { on membership } \\
\text { cancellation }\end{array}$ & $\begin{array}{l}\text { Variable amounts, } \\
\text { withdrawals only } \\
\text { on membership } \\
\text { cancellation }\end{array}$ & $\begin{array}{l}\text { Uniform amount, } \\
\text { withdrawals only } \\
\text { on membership } \\
\text { cancellation }\end{array}$ & $\begin{array}{l}\text { Uniform amount, } \\
\text { withdrawals only } \\
\text { on membership } \\
\text { cancellation }\end{array}$ \\
\hline $\begin{array}{l}\text { Special Purpose } \\
\text { Savings }\end{array}$ & $\begin{array}{l}\text { Yes, withdrawal } \\
\text { on maturity }\end{array}$ & $\begin{array}{l}\text { Yes, withdrawal } \\
\text { on maturity }\end{array}$ & None & $\begin{array}{l}\text { Yes, withdrawal } \\
\text { on maturity }\end{array}$ \\
\hline Nominal Interest & $12 \%$ & $12 \%$ & None & $12 \%$ \\
\hline \multicolumn{5}{|l|}{ Loans } \\
\hline General features & $\begin{array}{l}\text { Savings linked, } \\
\text { repeat and } \\
\text { multiple }\end{array}$ & $\begin{array}{l}\text { Savings linked, } \\
\text { repeat and } \\
\text { multiple }\end{array}$ & $\begin{array}{l}\text { Not linked to } \\
\text { savings, repeat } \\
\text { but not multiple }\end{array}$ & $\begin{array}{l}\text { Linked to thrift } \\
\text { amount, repeat, } \\
\text { multiple loans } \\
\text { linked only to } \\
\text { voluntary savings }\end{array}$ \\
\hline $\begin{array}{l}\text { Interest on } \\
\text { General loans }\end{array}$ & $\begin{array}{l}24 \text { to } 36 \% \text { on } \\
\text { diminishing } \\
\text { balance }\end{array}$ & $\begin{array}{l}24 \text { to } 36 \% \text { on } \\
\text { diminishing } \\
\text { balance }\end{array}$ & $\begin{array}{l}24 \% \text { on } \\
\text { diminishing } \\
\text { balance }\end{array}$ & $\begin{array}{l}24 \text { to } 36 \% \text { on } \\
\text { diminishing } \\
\text { balance }\end{array}$ \\
\hline $\begin{array}{l}\text { Interest on } \\
\text { Housing loans }\end{array}$ & $\begin{array}{l}18 \% \text { on } \\
\text { diminishing } \\
\text { balance }\end{array}$ & $\begin{array}{l}15 \% \text { on } \\
\text { diminishing } \\
\text { balance }\end{array}$ & $\begin{array}{l}\text { No Housing } \\
\text { Loans }\end{array}$ & $\begin{array}{l}\text { No Housing } \\
\text { Loans }\end{array}$ \\
\hline $\begin{array}{l}\text { Repayment } \\
\text { period and } \\
\text { schedule }\end{array}$ & $\begin{array}{l}\text { Flexible, variable } \\
\text { with amount and } \\
\text { purpose. } \\
\text { Borrower gives } \\
\text { schedule, but } \\
\text { within limits set } \\
\text { by the SHGs. }\end{array}$ & $\begin{array}{l}\text { Flexible, variable } \\
\text { with amount and } \\
\text { purpose. } \\
\text { Borrower gives } \\
\text { schedule, but } \\
\text { within limits set } \\
\text { by the SHGs. }\end{array}$ & $\begin{array}{l}\text { Fixed - } 20 \\
\text { monthly } \\
\text { installments }\end{array}$ & Fixed \\
\hline
\end{tabular}

\section{Apex Federations}

Apex federations are generally categorized into those that provide financial services and those that are not. All the federations included in this study are involved in financial intermediation, but to varying extents. KVK and SPMS mobilize loan funds from lending organizations such as development banks and housing banks. In SPMS, SHGs could not receive loans from banks until recently and SPMS was the only source of loans for the SHGs. In contrast, KVK primarily supplements loans available to SHGs from the SHGbank linkage program. ' SMMS has not obtained loan funds but has received grants from UNDP that has been capitalized and is used for lending to SHGs (through VOs). The thrift cooperative federation does not receive loans, but lends the mandatory deposits ( 5 percent of their thrift) that the thrift cooperatives make with the federation.

\footnotetext{
${ }^{9}$ However, the recent introduction of housing loans (not yet directly available to SHGs) has significantly increased the proportion of KVK funds in SHG liabilities.
} 
Insurance is another crucial service offered or facilitated by the federations. KVK, SPMS, and the thrift cooperative offer life insurance schemes. The federations implement some of these schemes independently, while offer others in collaboration with commercial insurance companies. KVK and SMMS also offer cattle insurance for their members in cooperation with commercial insurance companies.

The apex federations also offer non-financial services such as educational support, livestock care and technical support for housing. SPMS has recently started providing HIV counseling and preventive healthcare. KVK runs a training center that imparts skill trainings on handicraft production and computer software packages. KVK and SPMS provide technical support for house construction and purchase of materials (both employ technical personnel for this). SPMS operates a housing material production unit, which produces low cost construction materials.

Though several services provided by the federations directly benefit individuals who are members in the primary groups, more crucial are the services provided to the SHGs. These include accounting support and auditing, monitoring and co-ordination, conflict resolution, and training services. Monitoring is central to improving the performance of SHGs, especially lowering default rates. Training for SHG members, leaders, and staff includes both formal classroom training and exposure visits to other well-functioning SHGs. KVK and SPMS have exclusive staff for all these areas.

\section{Why Federate SHGs}

The primary purpose of federating SHGs is to ensure the sustainability of SHGs. SHG federations help SHGs internalize all operational costs and reduce the cost of promoting new SHGs. Federations also build solidarity among SHG members by helping them see SHGs as part of a larger organization. This helps build member stake in the SHGs. Building ownership is important in SHGs since, typically, they are not self-promoted organizations, and the small size of SHGs makes it difficult for their members to visualize them as sustainable organizations. This section, drawing on the study cases, discusses factors that enable SHG federations to contribute to SHG sustainability. Section 2 of Annex 3 provides a detailed description of the functions performed by the SHG federations.

\section{Economies of Scale}

SHGs require several essential services that can be provided neither by individual SHGs themselves nor are available on the market at a scale needed by the SHGs. Most of these services are initially provided by the promoter organizations, but this is not sustainable since providing these services is neither the core activity nor among the core competency of the promoter organizations. Federations make sustained availability of these services more likely as it provides the necessary scale at which the services can be offered and the possibility of it being designed to suit the requirements of the SHGs. Recovering the costs is easier because SHGs do not confuse service provision with the promotional process. 
Audit is one such service that all federations studied here provide. Even when external auditors audit SHG accounts, federations help SHGs prepare for the process. Capacity building of SHGs is another such service; all the SHG federations studied provide capacity building services to their member SHGs. This involves training the SHG members, leaders, and SHG accountants. By providing a common forum for review of SHG performance and enabling them to plan for further development, federations also create space for internal learning.

Finally, federations help resolve conflicts. Such conflicts include those between SHG members, between SHGs, between SHGs and village leaders, and between SHGs and banks. Federations make available leaders and staff acceptable to both sides of a conflict to mediate such conflicts. In some cases, the federation strengthens the position of SHGs when the conflict is with outsiders.

\section{Reduction in Transaction Costs}

The main innovation of the SHG-bank linkage program was in reducing the costs that banks incur when lending to the poor. This was achieved because SHGs consolidate what could potentially have been 15-20 individual accounts into one single SHG account. Even on a per account basis, the costs of lending to SHGs appear to be less than that of lending directly to individuals. A NABARD study found the transaction cost on a SHG loan account to be $35.6 \%$ less than that of an average priority sector loan on the first loan and $55.7 \%$ less on the second loan (Puhazhendhi.V. 2000).

Apart from reduction of paperwork and staff time because of account consolidation, transaction costs for banks are low because SHG promoter agencies bear a high proportion of the SHG loan monitoring costs. Although bank staff are expected to make periodic visits to the SHGs and lend to them based on factors such as the quality of accounts, regularity of meetings and credit history (for repeat loans), the reputation of the promoter agency plays a significant role in the bankers' decision. Banks partly substitute the task of assessment and monitoring with reputation of the promoter organization. However, this social collateral that the promoter organization provides becomes insufficient when the number of SHGs increase and when amounts being lent to individual SHGs increase. In such situations, SHG federations appear to fulfill this role better as they are nearer to SHGs and have better information on SHG performance. In the case of large promoter organizations, SHG federations are also closer to the bank branches lending to SHGs.

While the lower transaction costs to banks because of the presence of SHG federations is yet to be reflected in interest rates (even after lending rates to SHGS were deregulated), insurance companies already offer discounted premiums when federations facilitate sale of insurance products to SHG members. The federations offer a level of aggregation that makes it financially viable for the companies to deal with this clientele. Federations also diminish the probability of fraudulent claims because of their better local knowledge. 


\section{Reduction in Delinquency Rates}

Through better monitoring and the provision of both positive and punitive incentives, federations appear to reduce loan default - both within SHGs and from SHGs to banks. Federation leaders and staff intervene on behalf of SHGs when a member consistently defaults on her loans from an SHG. In the case of bank loans to SHGs, banks share information with the federation on a periodic basis, and the federation follows up on defaults. Availability of loans and other services from the federation, the peer pressure from other SHGs, and social prestige associated with SHGs having good repayment record are incentives for SHGs to maintain timely loan repayment performance. In the long-run, reduced transaction costs and timely loan repayments should have a positive impact on the interest rates on loans to SHGs.

\section{Providing Value-Added Services}

Micro-insurance services are the main value added service provided by three federations. Federations provide these services either on their own or in collaboration with insurance companies. These services are valuable since the insurance companies either have little reach in the populations being served by the federations or do not have products suitable to the needs of the poor. The information advantage of a member-owned entity and an established financial system allows the federations to provide insurance services in spite of the relatively small number of clients. Nevertheless, the small size of the federations does limit the benefits the federations can offer, especially in cases of catastrophic events.

At present, the federations offer only minimal education, health, and livestock support services. The quality and quantity of these services could increase when federation resources and their capacity to manage these resources improve. There is likely to be significant demand for these services, especially in rural areas where their availability is scarce. The federations could provide the services on a cost basis or in collaboration with government agencies that are currently responsible for providing these services but are ineffective in doing so. Services that federations could potentially provide include supply of essential food commodities, currently provided by Fair Price Shops run in a highly inefficient manner by government-controlled cooperatives (provided government controls and restrictions on margins and volumes are reduced), childcare services for preschool children (currently provided directly by the state), and supply of agricultural inputs and marketing of produce in places where private market organizations are absent or weak.

\section{Reduction of Promotional Cost}

The federations studied employ some of their income, staff time, and volunteer time of federation and SHG leaders in the promotion of new SHGs. In all the federations studied, the federation leaders perceive promotional activity as one of their key responsibilities. Since, federations possess better local information and have greater legitimacy because of their being based in the community, they are able to form groups faster and at a cheaper cost than when this is done exclusively by the promoter agency. 
Increased outreach also contributes to the viability of the federations by helping them to increase their membership to levels necessary to maximize economies of scale. Reduction in promotional cost also contributes to sustainability of SHG-based microfinance on a macro level as it reduces the overall promotional investment needed.

\section{Empowerment}

Federations expand empowerment beyond that achieved by SHGs in various ways. First, federations provide an identity to the SHG members that they are part of a large organization and builds solidarity among the members of different SHGs.

Second, SHG federations require human resources of much higher capacity than that required by individual SHGs because of the variety of tasks they perform. The members in the boards of the federations build on the organizational experience they have gained in the SHGs, and also gain from the more focused capacity building efforts the promoter agencies are able to undertake at the level of federations. In addition, federations provide enhanced opportunities for the local youth recruited as staff of these federations to increase their skills and knowledge. Both of these build local human capital, a significant contribution to to long-term community capacity.

Third, while SHGs provide an opportunity for the poor to save, obtain loans, and interact with the promoter organizations and banks, federations have the potential to produce leaders. At least some of the federation board members interviewed conveyed a sense of purpose and pride in the roles performed by them. Federation board members have gained the respect of the community that includes the non-poor because of the scale of the organizations they lead. The scale of the federations also creates opportunities for the federation leaders to deal with mainstream institutions of the society on more equal terms than possible for SHGs.

\section{Financial Analysis}

\section{Profitability}

The previous section described the various services provided by SHG federations. The SHG federations themselves receive support from the promoter organizations, either financial or personnel, or both. Several operational costs of SHGs - accounting, auditing, training, etc. are borne by the SHG federation. It appears unlikely that individual SHGs would be able to self-provide all services they require even at a future date. Hence, the analysis conducted here estimates if SHGs have adequate income not only to pay for all their direct costs but also that incurred by their federation(s) and the promoter agency in providing services to SHGs. Similarly, in the case of federations, the analysis estimates the adequacy of the federation(s) income to pay for all their direct costs as well as operational support from promoter agency. However, expenses of the promoter agency in previous years are not included in the profitability calculation. The cumulative expenses of the promoter agency in promoting SHGs and SHG federations are analyzed separately under promotional costs. 
For the federations, only operational self-sufficiency is calculated. For SHGs, both operational self-sufficiency and financial self-sufficiency is computed.$^{10}$ Financial viability analysis could not be done for SMMS because costs at the apex federation level were not available. ${ }^{11}$ For the analysis of SHG profitability, the consolidated income and expenses of all SHGs is used. The federation's costs, including that incurred by the promoter organization - both direct subsidies and cost of personnel on seconded to the federations, is added to the SHG costs to get profitability of SHGs. This approach, while not revealing if individual SHGs are profitable, indicates if all the SHGs together are profitable. The federation profitability analysis estimates the adequacy of the federation's actual income to meet its costs. Annex 1 describes in detail the profitability analysis methodology. Annex 2 presents the consolidated financial statements of the SHGs and SHG federations, the actual prices in the SHGs, and the shadow prices used for calculating financial-self sufficiency.

The profitability analysis reveals a trend of increasing operational self-sufficiency for the federations, reaching over 90 percent for KVK (Table 3) and over 100 percent for SPMS (Table 4). Operational and financial self-sufficiency of SHGs in KVK was over 100 percent in 1998-99, decreased to 83 percent in 1999-00, and increased to 99 percent in 2000-01 (Table 5). The reduction in self-sufficiency in 1998-99 is caused by the 122 percent increase in operational expenses and 148 percent increase in financial expenses that were not compensated by the 76 percent increase in operational income. The KVK management attributed this to the significant expansion of activities during that year. SHGs in SPMS have over 100 percent operational and financial self-sufficiency.

Similar ratios for operational and financial self-sufficiency indicate a low level of subsidies, a notable feature, different from most MFOs. A weakness of the SHG profitability analysis is non-inclusion of loan loss provision costs. SHGs do not maintain information on portfolio quality. Information on overdue installments and age categorization of overdues is collected at the SHG level, but consolidated information for all SHGs was not available. SHGs in both federations maintain a loan loss reserve created from a fee of $1 \%$ of loans to members. However, it is not clear if this is adequate to cover possible loan losses and increases in this could affect overall profitability analysis significantly. Additional research might be needed to determine the impact of poor quality loans on the sustainability of SHG federations because for the average quality federations this may well be a significant cost.

The profitability analysis indicates that SHG federations have the potential to achieve financial viability though this appears to take a relatively long time. While SPMS has taken nine years to achieve this, KVK seems likely to achieve it in seven. DHAN Foundation expects SHGS and SHG federations currently being promoted to achieve financial selfsufficiency in five years. DHAN attributes the decrease in time to the increased readiness of

\footnotetext{
10 A modified version of Consultative Group to Assist the Poorest (CGAP) definitions are used. While CGAP includes in kind personnel costs incurred by promoter agency in Adjustments, this study includes it in Operational Expenses itself. Doing so allows operational self-sufficiency to reflect operational subsidy and financial self-sufficiency to reflect financial subsidy.

${ }^{11}$ Although, profitability analysis was not attempted for SVAWTC and its member thrift cooperatives, they appear to be profitable. Loan losses appear to be marginal, they do not receive any operational subsidies from the promoter organization.
} 
the financial institutions to lend to SHGs and to improvements in the organizational systems of the federations.

Table 3. Profitability of KVK federations

\begin{tabular}{lrrr}
\hline \multicolumn{1}{c}{ Particulars } & $1998-99$ & $1999-00$ & $2000-01$ \\
\hline Operational Income & 234,196 & 797,227 & $2,423,971$ \\
Financial Expenses & 22,720 & 456,762 & $1,774,387$ \\
Operational Expenses & 189,908 & 411,984 & 637,125 \\
DHAN expenses & 163,495 & 362,560 & 175,992 \\
Operational Surplus / Loss & $(141,927)$ & $(434,079)$ & $(163,533)$ \\
Operational Self Sufficiency (\%) & 62 & 65 & 94 \\
\hline
\end{tabular}

Table 4. Profitability of KKVS SHGs

\begin{tabular}{lrrr}
\hline \multicolumn{1}{c}{ Particulars } & $98-99$ & $99-00$ & $00-01$ \\
\hline Operational Income & $1,087,087$ & $1,911,642$ & $3,815,099$ \\
Financial Expenses & 383,091 & 950,264 & $2,102,390$ \\
Operational Expenses & 604,213 & $1,340,272$ & $1,741,284$ \\
Operational Surplus / Loss & 99,783 & $(378,894)$ & $(28,575)$ \\
Adjustments & 43,075 & 19,789 & 14,932 \\
Operational Self Sufficiency (\%) & 110 & 83 & 99 \\
Financial Self Sufficiency (\%) & 106 & 83 & 99 \\
\hline
\end{tabular}

Table 5. Profitability of SPMS federation

\begin{tabular}{lrrr}
\hline \multicolumn{1}{c}{ Particulars } & $1998-99$ & $1999-00$ & $2000-01$ \\
\hline Operational Income & $1,024,379$ & $1,339,794$ & $2,438,960$ \\
Financial Expenses & 331,813 & 563,226 & $1,283,772$ \\
Operational Expenses & 782,024 & 840,160 & 986,110 \\
Operational Surplus / Loss & $(89,458)$ & $(63,592)$ & 169,078 \\
Operational Self Sufficiency (\%) & 92 & 95 & 107 \\
\hline
\end{tabular}

Table 6. Consolidated Profitability of SPMS SHGs

\begin{tabular}{lr}
\hline \multicolumn{1}{c}{ Particulars } & 2000-01 \\
\hline Operational Income & $5,997,195$ \\
Financial Expenses & $3,673,235$ \\
Operational Expenses & $1,859,282$ \\
Operational Surplus / Loss & 464,678 \\
Adjustments & 29,201 \\
Operational Self Sufficiency (\%) & 108 \\
Financial Self Sufficiency (\%) & 108 \\
\hline
\end{tabular}




\section{Cost of Promotion}

The costs of promoting SHGs and their federations are primarily twofold: direct promotional cost - operational support to SHGs and SHG federations (including costs of staff seconded to federations, local training costs, etc.) - and administrative costs of the promoter agency. Administrative costs of the promoter agency include costs of senior staff whose services are available across several federations and organizational overheads. Administrative costs of the promoter agency are considered as program management costs and not included in the promotional costs estimates presented here.

Data for the full period of existence of the federation were only available for KVK. Through October 2001, when DHAN Foundation ceased providing financial support to KVK, it incurred approximately Rs.1.77 million (US\$ 37,659) in direct costs in promoting KVK, including capital grants of Rs.0.57 million (US\$12128). This figure implies a cost of around Rs.7080 (US\$ 151) per SHG (assuming 250 groups). ${ }^{12}$ In a recent funding proposal, DHAN has estimate total promotional expense of Rs.2.3 million (US\$ 48936) per federation and Rs.9200 (US\$196) per SHG for support over a period of five years. This cost would cover the promotional costs required to promote 250 SHGs, 10 CDAs and an apex federation. SERP envisages a budget of US $\$ 16.6$ million (Rs.780 million) to promote 18,000 new SHGs and support 20, 000 existing SHGs in 180 mandals. This works out to US\$437(Rs.20,532) per SHG and US\$92,222 (Rs.4.3 million) per mandal-federation (equivalent of SMMS). ${ }^{13}$

Although no studies that estimate cost of promotion for SHG federation appear to be available, several estimates exist for SHG promotional cost. These vary widely from Rs.1350 (US\$29) to Rs.16,000 (US\$340) to develop a new SHG to a stage when it can obtain loans from a bank (FWWB 2002, cited in Harper 2002). Harper and others (1998) (as cited in Harper 2002) estimated that it cost a typical NGO Rs.8250 (US\$176) to develop an SHG for linkage with banks. These estimates are however not strictly comparable to the estimates of SHG promotional cost for DHAN and SERP (because their estimates include costs of federations), and because of the different methodologies used.

\section{Issues and Challenges: Internal}

Previous sections described potential benefits of SHG federations, and the possibility of SHGs and SHG federations becoming financially viable, if adequate initial investment in their development is made. This Section and Section 7 discuss areas that issues that challenge the sustainability of SHG federations.

\footnotetext{
12 Currently there are 242 groups. The costs for previous years are not adjusted for inflation, and hence real costs are likely to be slightly higher than this amount.

13 The cost estimates given here refer only to the direct cost of promoting the SHGs and SHG federations. The cost of program administration and other expenses are not included to make the data comparable DHAN's cost projection.
} 


\section{Governance}

Illiteracy and insufficient organizational experience of most SHG federation board members constrain the governance capacity in SHG federations. This constraint, inherent to an organization of poor women, affects the ability of the federation boards to effectively perform oversight functions. During the interviews, few board members were able to identify oversight of staff as one of their roles. Insufficient understanding of auditing expressed by the board members also reflected this weakness; board members perceived auditing more as a means to check for accounting errors rather than as a check on management.

The promoter organizations are attempting to address this issue by building the capacity of the federation boards; the amount of training however appears inadequate. Enhancing the capacity of federation board members, especially in ability to perform oversight functions, is crucial if the federations are to become organizations that SHGs own and control. However, capacity building is likely to be inadequate if the board members do not have sufficient time to practice what they learn; they have to be on the board long enough to learn from experience. Too short tenures are a problem in one of the federations studied, where officeholders change every year. Giving board members (or at least the Chairpersons) sufficient financial compensation to permit them to spend more time on federation-related duties may contribute to their effectiveness.

Lastly, improved governance, in the long-term, can only be achieved when leaders with a vision for the organization and the ability to work with leaders in other organizations in the society emerge. More of the forums such as the Bank-linkage steering committee constituted by DHAN, where federation leaders interact with senior officials of the banks, need to be facilitated by the promoter agencies. There is also a need for federation leaders to have increased interaction at the local level - with the panchayats (local governments), with the block/mandal administration, and with local business leaders. Constituting advisory boards with members representing local institutions and local leaders could serve this function. Additionally, this would provide federation leaders with an independent source of information (other than the promoter organization and the auditors).

\section{Staffing}

One of the strengths of SHG federations studied here is its capacity to have staff to perform specialized functions. Furthermore, most or all the staff are locally recruited. In SPMS, all staffs except the chief executive and general manager are local staff; in KVK, this is the case for all staff except the chief executive and the financial manager. All staffs inclusive of the chief executive are local in SMMS. The practice of seconding promoter agency staff to executive positions in the federations does however raise accountability issues.

DHAN justifies the practice of seconding its staff as chief executives and financial managers of SHG federations (apex) as part of its promotional role. This however does not explain why even federations that are well established and have adequate income have not recruited chief executives from elsewhere. The chief executives of the federations have dual 
reporting requirements - to the federation board and to the promoter organization, and the federation boards find it difficult to set the agenda for their chief executives. SHG members as well as federation boards also appear to perceive the chief executive more as benevolent do-gooders than as an employee. The board in one federation suggested that it felt inhibited in questioning the chief executive, while it is able to do so with other staff. A possible reason (apart from their being promoter agency staff in the case of DHAN) could also be that the chief executive in two SHG federations had also been involved in promoting the federation.

Under the District Poverty Initiatives Project, SERP expects its contractual staff involved in promoting SHGs and SHG federations to become federation staff at the end of the project period. Not having staff involved in promotional activities continue as chief executives after federation promotional activity is completed, might help the boards to hold their chief executives more accountable. However, the long-term strategy has to be in helping the federations recruit professionals directly. The promoter agencies could continue to provide advisory services.

\section{Processes and Systems}

Good systems provide efficient means to carry out routine functions of an organization. Such systems should be cost effective and easy to use, while ensuring sufficient controls and efficiency. All the federations studied need to improve their systems and processes. Risk management, repayment monitoring, and financial management are some of the systems which need increased attention. Though delinquency does not appear to be a significant problem in the federations studied, it is not possible to be definitive about this in the absence of systems that provide consolidated information on portfolio quality or age of overdue installments.

Sound processes contribute equally to effective organizations. Governing body meetings, annual general body meeting, and annual staff performance review are key organizational processes. The understanding of boards and staff on the value of these processes and their practice needs further improvement. In some cases, too much participation (such as participation of all staff in the governing body meetings in SMMS) undermines the functionality of these processes. Good systems and processes would also facilitate their easier replication. Regular system audits within the federations and adoption of best practices would hasten the development of sound organizational practices. The promoter agencies should facilitate these processes and promote enhanced mutual learning among the SHG federations.

\section{Accountability to SHGs}

Accountability in a member-owned organization depends primarily on ability of the members to hold the organization accountable. One of the major factors influencing this ability is the awareness of SHG members of their rights and duties as members as well as their capacity to use this awareness. As in the case of governance, the high level of illiteracy and lack of organizational experience of most members is a constraint for most SHG members in performing this role. Learning through experience contributes significantly to 
SHG members overcoming this constraint. However, there is a need for increased focus of the promoter agencies on building the awareness among SHG members regarding the roles of SHGs in holding SHG federations accountable.

An equally important determinant of federation accountability is the source and mode of federations' income. A federation that earns the major part of its income from SHGs is more likely to be accountable to the SHGs than a federation that earns its income alternative sources such as promoter agency or investments. All the SHGs federations studied here primarily earn their income from interest income on loans SHGs. DHAN stopped providing all financial support to SPMS in March 2001, and to KVK in October 2001. Since then, the federations are reimbursing DHAN the salaries of the professionals seconded to these federations. However, the mode of earning such income is also likely to influence accountability. When SHG federations earn income primarily from interest spread, SHGs tend to see the federation more as a lending agency, and less as their federation.

Since the financial year 2001-2002, KVK (and other federations supported by DHAN) have shifted to a system where they earn their income primarily from service charges paid by SHGs. The service charges are a percentage of the consolidated SHG loan portfolio; hence, SHGs with larger loan portfolios pay more than SHGs with smaller portfolios. The percentage itself is determined each year by the federation based on an approved annual budget. This system, on the one hand forces the federation to justify their expenses to the SHGs, and on the other hand, conveys to the SHGs that they need to bear the costs of the federation. In such a system, SHGs could withhold the service charges if it is not satisfied with the services provided by the federation. Although the methodology of estimating service charges needs improvement to better link services provided and the service charges, having federation income depend primarily on service charges rather than interest spread is a likely to enhance federation accountability to SHGs. ${ }^{14}$

\section{Retaining Core Competency while Diversifying}

Financial organizations require very different management processes than nonfinancial ones. This raises the question whether organizations such as SHG federations can provide non-financial services without adversely affecting the financial services it provides. Increasing recognition of the limits of microfinance in directly affecting poverty perhaps justifies attempts to provide non-financial services to which they have no access or inadequate access (livelihood support, education, health, etc.). Additionally, in memberbased organizations, successful provision of microfinance naturally leads to a demand for other services. All SHG federations in this study provide non-financial services in addition to microfinance services. Federations supported by SERP also implement community infrastructure projects.

While SHG Federations could and perhaps should take up new activities that benefit their members, it might prove counter-productive to do so before they have evolved fully as

\footnotetext{
${ }^{14}$ Apart from accountability reasons, federations also need to shift to service charges as its primary income source because dependence of SHGs on the federation for loans would reduce as SHGs' own funds and direct access to banks increases.
} 
microfinance organizations, and have sufficient resources and capacity for these additional functions. There is also a risk that promoter agency's attention is diverted to developing the new functions before core functions of the SHGs and the federations are sufficiently established. Hence, it is advisable that SHG federations establish their competency as microfinance organizations before diversifying into other activities.

\section{Issues and Challenges: External}

\section{Capacity of Promoter Agencies}

Limited organizational capacity of promoter agencies is perhaps the most crucial constraint in developing sustainable SHG federations. Capacity of the promoter agencies primarily determines the quality of SHG federations. Promotion of federations requires institution-building skills beyond that required in promoting SHGs. Very few promoter agencies -both NGOs and government agencies possess skills.

NABARD should identify SHG federation models that add value to the SHGs and take initiatives to build the capacity of SHG promoter agencies in promoting such federations. As in the case of SHG promotion, these initiatives could include exposure visits to such federations and structured training programs. Promoter agencies that have promoted such federations could be used as lead trainers. Additionally, new organizations that focus exclusively on capacity building of promoter agencies and SHG federations also need to be promoted in states with significant number of SHGs. Donor agencies could support the establishment of such organizations. An effort in this direction is the creation of Andhra Pradesh Mahila Abhivrudhi Society (APMAS with the support of DFID and CARE-India. APMAS works on quality assessment and enhancement of SHGs, SHG federations, and SHG promoter organizations.

\section{Inadequate Knowledge Base on SHG Federations}

No estimates are available on the number of federations in existence, their outreach in terms of SHGs supported, the extent of the services provided by them, or the amount of financial resources handled by them. NABARD should play a leading role in improving the knowledge base. A database of SHG federations needs to be created. Assessments and impact studies of the different federation models, and development of performance standards and rating indices need to be carried out. APMAS is in the process of developing a rating index. NABARD should also facilitate of mutual learning among the promoter agencies that have promoted SHG federations and the federations themselves.

Some aspects of SHG federations that need further study include: (a) the effect of federating on transaction costs and delinquency rates; (b) the effect of federating on SHG promotional costs, and outreach of the SHG-Bank Linkage program; (c) cost-benefit analysis of federating; (d) analysis of SHG federations compared to other federated models in microfinance - village banking and credit unions; and (e) impact of SHG federations on community social capital. 


\section{Legal Framework}

SHG federations are mostly registered as charitable societies. This does not provide an appropriate legal framework for organizational character and purpose of the SHG federations. The member-based organizational structure, the economic character of the organization, and the primary objective being to benefit members make cooperatives appear to be an appropriate organizational form. However, this is not a feasible option because of the regressive nature of the typical cooperative law that allows excessive government control. An exception appears to be the new cooperative laws enacted in a few states.

Andhra Pradesh was the first state to enact such a law. Several SHG federations in Andhra Pradesh are already registered under this law. ${ }^{15}$ This law grants functional autonomy to cooperatives not receiving funds from the government, and the regulatory powers of the government are limited to approaching independent tribunals in case of a violation of the norms. Although, by registering under this law, the federations legally become primary cooperatives because this laws permits only individuals or cooperatives to become members, it provides the federations a legal framework better suited to their organizational character. Operationally, the federations continue to operate as SHG federations. SERP has facilitated the registration of the village-level federation of SHGs (the VOs) under this law. In the case of three-tier federations such as those supported by SERP, the third tier federation could be registered as a federation of the village-level cooperatives (operationally village-level federation of SHGs).

Laws similar to the one in Andhra Pradesh have now been enacted in seven more states. SHG promoter agencies need to explore the characteristics of the laws passed in each state and assess the advantage and disadvantage of registering SHG federations under these laws. In states where such laws are yet unavailable, promoter agencies could work with organizations such as CDF that are advocating the enactment of such laws to ensure that they are more amenable for use SHG federations.

\section{Discussion and Conclusions}

SHG-based microfinance in India has significant achievements: over 10 million people reached, Rs. 8 billion (US $\$ 170$ million) in savings mobilized, Rs.20 billion (US $\$ 425$ million), and over $95 \%$ on-time repayment rate on these loans. However, the financial sustainability of SHGs has not been clear because several of their costs are subsidized by organizations that had promoted them, and because of less than market cost paid by SHGs on loans from banks. Similarly, their organizational sustainability has been suspect because of their small size, which limited the financial and human capital available to them, and thereby the services they could provide themselves.

NABARD has played a crucial role in the development of the SHG microfinance

\footnotetext{
${ }^{15}$ Andhra Pradesh Mutually Aided Cooperative Societies Act (AP MACS Act 1995) after significant lobbying efforts led by CDF. CDF has also played a significant role in getting similar law passed in some other States in the country. In Andhra Pradesh, many cooperatives, currently incorporated under the earlier restrictive act (which continues to exist), are incorporating under the new act after repaying the government's share capital.
} 
model through its promotional activities and refinancing activities of the SHG-Bank Linkage program. It has been focusing, perhaps justifiably given the slow initial progress of the program, on increasing the outreach of SHGs and strengthening their linkage with the banking system. However, given the exponential increase in the program in the recent years and similar trends observed in other microfinance programs around the world (including that of Grameen Bank) (World Bank 2003), the focus needs to shift to sustaining the benefits provided by SHGs.

Despite the considerable achievements of the SHG-bank linkage program, sustainability of SHGs has not been clear. The extent of sustainability and factors determining sustainability are not known. Knowledge on impact is also inadequate. The need to investigate these issues is long overdue. Factors those are likely to make the benefits of SHGs sustainable need to be identified. Fundamental questions such as whether SHGs need to be sustainable for the program benefits to be sustainable need to tested. This study assumes the SHGs need to be sustainable and suggests that SHG federations have the potential to contribute to this. This suggestion needs to be tested further.

SHG federations studied for this paper provide several services to their member SHGs. These services help the SHGs gain economies of scale, obtain value-added services, reduce transaction cost, and enhance empowerment, thereby contributing to organizational sustainability of the SHGs. The financial analysis conducted for two federations indicates that both SHGs and SHG federations can be financially viable even when all costs, including those subsidized by the promoter agency, are accounted for.

Achieving financial sustainability appears to be less of a challenge for SHG federations than achieving organizational sustainability. Rather than whether a SHG federation can become financially sustainable, the questions appear to be: how long it would take, how much promotional investment would be needed, and what the success rate of such a transformation process would be for the average initiative. Organizational sustainability of SHG federations is dependent on improvements being made in federation governance, staffing, and organizational processes and systems. Accountability of the federations to SHGs should be strengthened by building SHG capacity to hold their federations accountable and designing institutional arrangements that provide incentives for federations to be accountable to SHGs. Limited capacity of most promoter agencies, inadequate knowledge base on SHG federations, and lack of suitable legal frameworks are major constraints in developing sustainable SHG federations.

Lastly, a few notes on interpreting the findings of this study. First, the paper does not deal with all the issues related to SHG federations. The discussion paper by Shashi Rajagopalan gives a good overview of several issues not dealt with in this study (APMAS 2003). Second, though all three federations studied in this paper offer financial services, the paper does not imply that this is essential for sustainability. SHG federations or other service provider organizations such as the Resource Centers promoted by MYRADA, which do not provide financial services, could also be sustainable if they provide services that add value to the SHGs and the costs of providing such services are recovered in the form of service charges.

Third, it needs reiteration that this study is not an assessment of SHG federations. 
Rather, it is an exploratory study that explores the potential of SHG federations in making SHGs sustainable, while themselves becoming sustainable. A more representative assessment of SHG federations in operation is provided by a recent study by Sa-dhan, a network of MFOs. Of the 27 SHG federations included in the study, only seven had sufficient data to permit financial analysis and among these seven only one was close to achieving full sustainability while five had moderate to high operational sustainability (Sa-dhan website). However, this study demonstrates that it is possible to promote SHG federations that provide a wide range of services that contribute to sustainability of SHGs while being financially viable themselves. If carefully designed and adequate promotional investments are made, SHG federations have the potential to become organizations that play a significant role in the development of not just their members, but also the larger community. 


\section{Annex 1. A Note on Financial Analysis Methodology}

The profitability of both SHGs and SHG federation(s) is analyzed. Only operational self-sufficiency is estimated in the case of SHG federations because of data limitations. In the case of SHGs, both operational and financial self-sufficiency is estimated. The formulae used to Operational Self Sufficiency and Financial Self Sufficiency are as follows:

$$
\begin{aligned}
& \text { Operational Self Sufficiency }=\text { Operational Income } /(\text { Operational Expenses }+ \\
& \text { Financial Expenses) } \\
& \text { Financial Self Sufficiency }=\text { Operational Income } /(\text { Operational Expenses }+ \\
& \text { Financial Expenses + Adjustments) }
\end{aligned}
$$

\section{Federations}

Operational Income includes all income from core activities; it does not include donations, sundry income, and bank interest income. Operational expenses include all operating costs of the federation(s) plus costs subsidized by the promoter organization, both in terms of direct transfers and cost of personnel on seconded to the federations. Financial expenses include all interest payments. The operational self-sufficiency of the federations indicates the percentage of operational costs of the federation met by its operational income. In the case of KVK, the operational self-sufficiency estimate only indicates the combined profitability of the apex federations and the CDAs.

SHGs

Operational income includes interest and fee income SHGs receive from their members, and does not include income such as penalties payments from members or grants from promoter organizations. Operational costs for the SHGs includes all administrative costs of SHGs and the federation(s) - including that provided by promoter organization. Federation(s) costs are included in the operational costs of SHGs on the assumption that federations provide services that are essential for the sustainability of the SHGs. Financial expenses are interest paid on loans and savings deposits. To calculate financial selfsufficiency, adjustments were made for the effect of inflation on general reserves and for the cost of funds. Interest rate charged by Basix, a private MFO, on their loans to SHGs (15 percent) is used as market cost of funds for general loans. Adjustment is not made for housing loans because the interest rates are comparable to that of housing loans available to other intermediaries such as housing societies.

The operational self-sufficiency of the SHGs indicates the percentage of operational costs of SHGs met by its operational income. However, the estimates for SHGs only indicate the combined profitability of all SHGs. They do not indicate profitability of individual SHGs or what proportion of SHGs associated with a federation is profitable. The analysis for SHGs in SPMS is done for one year only due to data limitations. 


\section{Annex 2. Financial Analysis: Prices and Financial Statements}

Table 7. Shadow Prices

\begin{tabular}{lrrr}
\hline \multicolumn{1}{c}{ Particulars } & 1998-99 & 1999-00 & 2000-01 \\
\hline Inflation rate & 11 & 6 & 3 \\
Inter-bank lending rate & 9 & 8 & 7 \\
Prime rate paid by commercial & & & \\
$\quad$ bank borrowers & 13 & 12.5 & 12 \\
Marginal commercial rate & & & \\
$\quad$ Available to SHGs & 15 & 15 & 15 \\
Exchange rate (Rupees/US\$) & 42.5 & 43.5 & 46 \\
\hline All rates in annual percent & & &
\end{tabular}

Table 8. Actual Prices in SHGs

\begin{tabular}{|c|c|c|c|c|c|c|}
\hline \multirow[b]{2}{*}{ Particulars } & \multicolumn{2}{|r|}{$K V K$} & \multirow[b]{2}{*}{$2000-01$} & \multirow[b]{2}{*}{$1998-99$} & SPMS & \multirow[b]{2}{*}{$2000-01$} \\
\hline & $1998-99$ & 1999-00 & & & 1999-00 & \\
\hline Interest paid on savings & 12 & 12 & 12 & 12 & 12 & 12 \\
\hline Cost of loans from bank & 12.5 & 12.5 & 12.5 & 12.5 & 12.5 & 12.5 \\
\hline Cost of loans from federation & 18 & 18 & 18 & 18 & 18 & 18 \\
\hline Cost of funds for housing & 13.5 & 13.5 & 13.5 & 15 & 15 & 15 \\
\hline $\begin{array}{l}\text { Interest charged to members on } \\
\text { general loans }\end{array}$ & 24 & 24 & 24 & 24 & 24 & 24 \\
\hline $\begin{array}{l}\text { Interest charged to members on } \\
\text { housing loans }\end{array}$ & 15 & 15 & 15 & 18 & 18 & 18 \\
\hline
\end{tabular}


Table 9. Financial Statements of KVK Apex Federation

\begin{tabular}{lrrr}
\hline \multicolumn{1}{c}{ Particulars } & $1998-99$ & $1999-00$ & $2000-01$ \\
\hline Income & & & \\
Interest on loans & 21,597 & 227,415 & 981,371 \\
Service charges/Fees & 4,200 & 27,100 & 31,550 \\
Donations & 47,379 & 53,140 & 79,200 \\
Sundry Income & 4,952 & 18,514 & 65,808 \\
\multicolumn{1}{c}{ Total } & 78,128 & 326,169 & $1,157,929$ \\
Expenditure & & & \\
Interest on loan & - & 212,448 & 804,470 \\
Salary and benefits & - & 12,660 & 95,852 \\
Travel & 402 & 5,082 & 21,062 \\
Office administration & 9,561 & 9,344 & 25,663 \\
Printing and Stationery & - & 10,373 & 29,849 \\
Training & 9,561 & 50,802 & 86,017 \\
Audit fee & 2,598 & & 1,500 \\
Sundry expenses & 756 & 1,610 & 21,094 \\
Profits & 55,250 & 23,850 & 72,422 \\
$\quad$ Total & 78,128 & 326,169 & $1,157,929$
\end{tabular}

\section{Equity and Liabilities}

\begin{tabular}{lrrr} 
Reserves and Surplus & 440,731 & 450,270 & 479,240 \\
Member Deposits & 364,035 & 872,635 & 973,470 \\
Loans & - & $2,896,000$ & $9,377,123$ \\
Specified Funds & 96,509 & 205,070 & 565,595 \\
Current liabilities & 1,000 & - & 700 \\
$\quad$ Total & 902,275 & $4,423,975$ & $11,396,128$ \\
Assets & & & \\
Land and Fixtures & 253,623 & 375,176 & $1,167,926$ \\
Deposits & - & 575,000 & 575,000 \\
Loans and Advances & 366,677 & $3,383,797$ & $9,584,839$ \\
Cash $\quad 281,975$ & 90,002 & 68,363 \\
$\quad$ Total & 902,275 & $4,423,975$ & $11,396,128$ \\
\hline
\end{tabular}

Item heads in original statements reorganized and relabeled for easier comparison. 
Table 10. Consolidated Financial Statements of KKVS CDAs

\begin{tabular}{lrrr}
\hline \multicolumn{1}{c}{ Particulars } & $1998-99$ & $1999-00$ & $2000-01$ \\
\hline Income & & & \\
Interest on loans & 98,210 & 390,529 & $1,038,411$ \\
Service charges/Fees & 110,189 & 152,183 & 372,639 \\
Donations & 25,800 & 15,779 & 24,643 \\
Sundry Income & 30,946 & 98,809 & 41,722 \\
\multicolumn{1}{c}{ Total } & 265,145 & 657,300 & $1,477,415$ \\
Expenditure & & & \\
Interest & 22,720 & 244,314 & 969,917 \\
Salary and benefits & 80,870 & 140,830 & 211,566 \\
Travel & 1,849 & 32,506 & 48,099 \\
Office administration & 37,173 & 13,778 & 17,523 \\
Printing and Stationery & 12,570 & 21,284 & 24,413 \\
Training & 4,764 & 32,713 & 43,924 \\
Audit fee & 2,231 & 5,800 & 8,000 \\
Sundry expenses & 27,573 & 85,575 & 32,412 \\
Profits & 75,395 & 80,500 & 121,561 \\
& 265,145 & 657,300 & $1,477,415$
\end{tabular}

\section{Equity and Liabilities}

Reserves and Surplus

Member Deposits

Loans

Specified Funds

Current liabilities

$$
\text { Total }
$$

\section{Assets}

Land and Fixtures

$\begin{array}{rrr}- & 704,264 & 733,224 \\ - & 170,803 & 318,202 \\ - & 3,329,545 & 8,511,827 \\ - & 812,113 & 1,169,766 \\ - & 151,930 & 153,017 \\ - & 5,168,655 & 10,886,035\end{array}$

Deposits

Loans and Advances

\begin{tabular}{lrr}
- & 62,600 & 97,996 \\
- & 424,300 & 525,506 \\
- & $4,333,581$ & $9,521,502$ \\
- & 348,174 & 741,031 \\
- & $5,168,655$ & $10,886,035$ \\
\hline
\end{tabular}

Total

$5,168,655$

$10,886,035$

Item heads in original statements reorganized and relabeled for easier comparison. 
Table 11. Consolidated Financial Statements of KKVS SHGs

\begin{tabular}{|c|c|c|c|}
\hline Particulars & $1998-99$ & 1999-00 & 2000-01 \\
\hline \multicolumn{4}{|l|}{ Income } \\
\hline Interest & $1,015,950$ & $1,879,625$ & $3,811,767$ \\
\hline Service charges/Fees & 71,137 & 32,017 & 3,332 \\
\hline Donations & 200,875 & 1,890 & 1,615 \\
\hline Sundry Income & 23,654 & 143,596 & 412,670 \\
\hline Total & $1,311,616$ & $2,057,128$ & $4,229,384$ \\
\hline \multicolumn{4}{|l|}{ Expenditure } \\
\hline Interest on loan & 207,990 & 587,839 & $1,388,234$ \\
\hline Interest on savings & 175,101 & 362,425 & 714,156 \\
\hline Service charges/Fees & 46,494 & 268,505 & 548,237 \\
\hline Travel & 31,492 & 42,141 & 93,637 \\
\hline Administration & 80,576 & 59,591 & 16,081 \\
\hline Printing and Stationery & 42,449 & 20,077 & 56,147 \\
\hline Training & 2,520 & 31,078 & 66,811 \\
\hline Audit fee & 12,110 & 23,325 & 30,841 \\
\hline Specified Funds & 20,713 & 154,404 & 315,414 \\
\hline Donations & 201,949 & 22,710 & - \\
\hline Sundry expenses & 21,787 & 256,259 & 449,028 \\
\hline Profits & 468,435 & 228,774 & 550,798 \\
\hline Total & $1,311,616$ & $2,057,128$ & $4,229,384$ \\
\hline \multicolumn{4}{|l|}{ Equity and Liabilities } \\
\hline Reserves and Surplus & 331,596 & 329,814 & 497,749 \\
\hline Member Deposits & $2,718,404$ & $5,122,666$ & $9,042,217$ \\
\hline Loans & $2,730,153$ & $6,307,886$ & $14,966,253$ \\
\hline Specified Funds & 325,484 & 557,793 & $1,005,299$ \\
\hline Current liabilities & 147,739 & 88,818 & 90,048 \\
\hline Total & $6,253,376$ & $12,406,977$ & $25,601,566$ \\
\hline \multicolumn{4}{|l|}{ Assets } \\
\hline \multicolumn{4}{|l|}{ Land and Fixtures } \\
\hline Deposits & 461,064 & $1,093,644$ & $1,704,265$ \\
\hline Loans and Advances & $5,693,377$ & $11,205,109$ & $23,575,939$ \\
\hline Cash & 98,935 & 108,224 & 321,362 \\
\hline Total & $6,253,376$ & $12,406,977$ & $25,601,566$ \\
\hline
\end{tabular}

Item heads in original statements reorganized and relabeled for easier comparison. 
Table 12. Financial Statements of SPMS

\begin{tabular}{|c|c|c|c|}
\hline Particulars & $1998-99$ & 1999-00 & 2000-01 \\
\hline \multicolumn{4}{|l|}{ Income } \\
\hline Interest on loans & 988,204 & $1,290,594$ & $2,390,795$ \\
\hline Service charges/Fees & 36,175 & 96,819 & 107,729 \\
\hline Donations & - & 6,900 & 106,399 \\
\hline Sundry Income & 62,072 & 59,083 & 42,466 \\
\hline Total & $1,086,451$ & $1,453,396$ & $2,647,389$ \\
\hline \multicolumn{4}{|l|}{ Expenditure } \\
\hline Interest & 331,813 & 563,226 & $1,283,772$ \\
\hline Salary and benefits & 414,554 & 382,254 & 326,308 \\
\hline Travel & 65,039 & 46,431 & 62,246 \\
\hline Office administration & 92,916 & 99,648 & 184,726 \\
\hline Printing and Stationery & 80,103 & 45,950 & 160,641 \\
\hline Training & 81,273 & 121,254 & 109,592 \\
\hline Audit fee & 12,000 & 12,600 & 21,827 \\
\hline Sundry expenses & 36,139 & 152,023 & 225,977 \\
\hline Profits & $(27,386)$ & 30,010 & 272,300 \\
\hline Total & $1,086,451$ & $1,453,396$ & $2,647,389$ \\
\hline \multicolumn{4}{|l|}{ Equity and Liabilities } \\
\hline Reserves and Surplus & $2,185,836$ & $2,298,420$ & $2,376,496$ \\
\hline Member Deposits & $2,124,333$ & $3,117,571$ & $4,233,458$ \\
\hline Loans & $4,451,110$ & $9,379,741$ & $18,000,377$ \\
\hline Specified Funds & 284,094 & 581,526 & $1,355,298$ \\
\hline Total & $9,045,373$ & $15,377,258$ & $25,965,629$ \\
\hline \multicolumn{4}{|l|}{ Assets } \\
\hline Land and Fixtures & 338,914 & 614,676 & $1,157,230$ \\
\hline Deposits and advances & 640,224 & $1,878,087$ & $3,096,808$ \\
\hline Loans & $5,674,371$ & $9,513,461$ & $19,998,159$ \\
\hline Cash & $2,391,864$ & $3,371,034$ & $1,713,432$ \\
\hline Total & $9,045,373$ & $15,377,258$ & $25,965,629$ \\
\hline
\end{tabular}

Item heads in original statements reorganized and relabeled for easier comparison. 
Table 13. Consolidated Financial Statement of SPMS SHGs

Particulars 2000-01

Income

Interest on loans

$5,214,850$

Interest on Deposits

133,945

Service charges/Fees

648,400

Sundry Income

22,810

Total

$6,020,005$

\section{Expenditure}

Interest on loan

2,390,795

Interest on deposits

$1,282,440$

767,333

86,223

59,475

65,000

122,603

Sundry expenses

$1,246,136$

Profits

Total

$6,020,005$

\section{Equity and Liabilities}

Reserves and Surplus

$10,138,066$

Savings

$21,102,350$

Loans

$13,743,057$

Total

44,983,472

Assets

Land and Fixtures

119,758

Deposits

$3,892,678$

Loans

$39,694,918$

Advances

679,022

Cash

597,095

Total

$44,983,472$

Item heads in original statements reorganized and relabeled for easier comparison. 


\section{Annex 3. Organizational Structure and Systems in the Federations}

\subsection{Organizational Characteristics}

\section{Structure}

There are three distinct organizations in KVK and SMMS, and two in SPMS and SVATWC (Figure1). The thrift cooperatives also have joint liability groups (groups of five) that are jointly liable for the loans of each individual in the group. SPMS has branch offices which are governed in a way similar to the CDAs in KKVS. SMMS federation structure is a tiered one. SHGs are members in the Village Organizations and the Village Organizations are members in mandal federation. In contrast, KVK has a nested structure with the SHGs as members in both the CDAs and the block federation.

The legal character of the federations and the primary organizations also vary. SHGs are not registered. The thrift cooperatives and the Village Organizations in SMMS are registered as Mutually Aided Cooperative Societies. The CDAs are not registered. Of the apex agencies, KVK is registered as a charitable trust, SPMS as a charitable society, and SVAWTC as a Mutually Aided Cooperative Society. ${ }^{16}$ SMMS is not registered.

\section{Governance}

Governance in SHGs is primarily the responsibility of all members since all members decide jointly on most issues (loans to members, applying for bank loans, membership in federation, expenses, etc.). SHG officeholders facilitate group meetings (during which savings and loan transactions take place), represent the SHG at the general body meetings of the federation and on transactions with banks, communicate information from the federation to the SHGs, and resolve conflicts among members. In thrift cooperatives, an executive committee of 12 members is responsible for management of the cooperative. They take most of the operational decisions such approving loan requests and overseeing the work of the accountant. The committee has a President, a Secretary, and a Treasurer elected from among them.

In the federations, governance is shared between the general body and governing body. In SPMS, KVK, and SVAWTC, the general body meets once a year; in SMMS, it meets every month. The governing body meets at least once a month in all the federations. In SPMS and KVK, the governing body members can remain in the board for a maximum of three years on being elected; they can however be reelected again. In SVAWTC, a third of the governing body members are elected every year through a staggered election process. The position of the President, Secretary, and Treasurer has to compulsorily change every year in SMMS.

\footnotetext{
${ }^{16}$ Non-profit organizations in India may register as Trusts, Societies, or non-profit companies. Trusts are the least regulated ones, while companies the most regulated.
} 
Figure 1. Organizational Structure of the Federations

SPMS

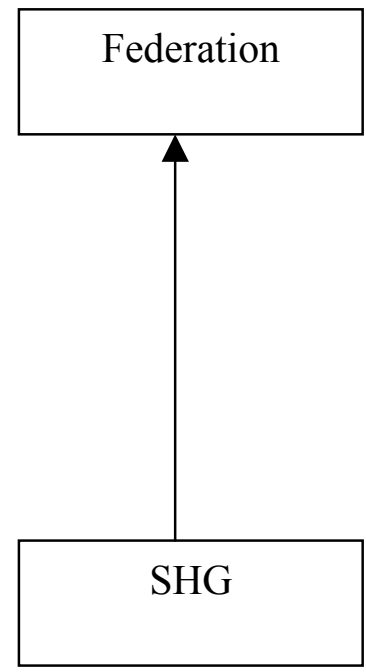

KVK

Block Federation

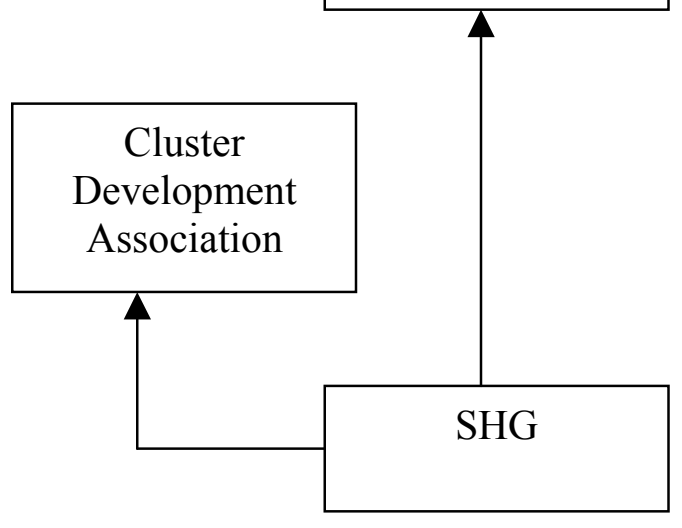

$S V A W T C$

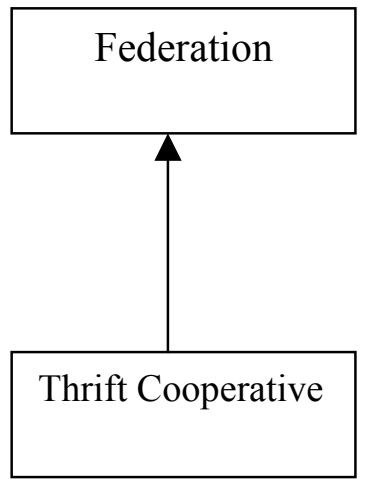

SMMS

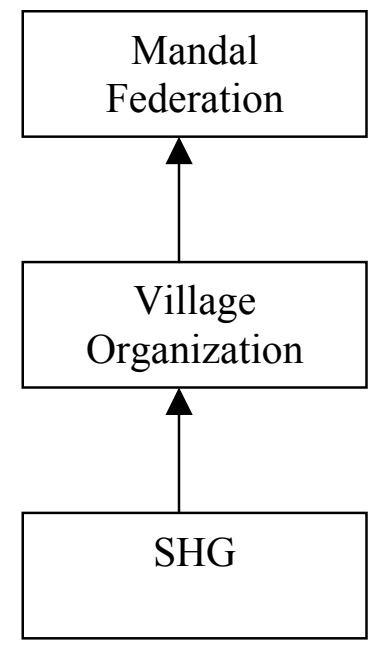


Table 14. Federation Structure, Staffing, and Funds

\begin{tabular}{|c|c|c|c|c|}
\hline Particulars & SPMS & $K V K$ & SMMS & SVAWTC \\
\hline \multicolumn{5}{|l|}{ Structure } \\
\hline Members & SHG & SHG & $\mathrm{VO}$ & TC \\
\hline General Body & $\begin{array}{l}2 \text { from each } \\
\text { SHG }\end{array}$ & 3 from each SHG & 3 from each $\mathrm{VO}$ & 2 from each $\mathrm{TC}$ \\
\hline Governing Body & 28 members & 16 members & 14 members & 7 members \\
\hline \multicolumn{5}{|l|}{ Staff } \\
\hline $\mathrm{CDA} / \mathrm{VO}$ & NA & Cluster Associate & $\begin{array}{l}\text { Animator / } \\
\text { Activist part time }\end{array}$ & NA \\
\hline \multicolumn{5}{|l|}{ Apex Federation } \\
\hline Managerial & Three & Two & One & None \\
\hline Accounts & Two & Five & One & One \\
\hline Others & Four & Seven & Nine & Nil \\
\hline \multicolumn{5}{|l|}{ Member Payments } \\
\hline Apex Federation & $\begin{array}{l}\text { Rs. } 100 \text { paid } \\
\text { annually by all } \\
\text { SHG members }\end{array}$ & $\begin{array}{l}\text { Rs. } 200 \text { per SHG } \\
\text { member one time } \\
\text { plus monthly } \\
\text { service charges }\end{array}$ & $\begin{array}{l}\text { Rs. } 100 \text { per SHG } \\
\text { paid annually }\end{array}$ & $\begin{array}{l}5 \% \text { of deposit in } \\
\text { the TCs }\end{array}$ \\
\hline $\mathrm{CDA} / \mathrm{VO}$ & Not Applicable & $\begin{array}{l}\text { Rs. } 1500 \text { per SHG } \\
\text { one time deposit } \\
\text { plus monthly } \\
\text { service charges }\end{array}$ & $\begin{array}{l}\text { Rs. } 10 \text { per } \mathrm{SHG} \\
\text { member per } \\
\text { month }\end{array}$ & Not Applicable \\
\hline
\end{tabular}

Notes:

a. All payments in SMMS and service charges in KVK are non-returnable. Other payments are returnable.

\section{Staffing}

SHG federations employ more staff than the thrift cooperative federation. As described earlier, the managerial staffs in SPMS and KVK are employees of DHAN. The SHG federations have separate staff for accounts and development functions, though the staffs in charge of development also monitor accounts periodically and assist in audit preparation. In SMMS, all the staffs are locally recruited, but their salaries are paid by SERP. SVAWTC has just one full time employee. This employee maintains the books of the federation and audits the accounts of the thrift cooperatives. However, the President works fulltime and is paid a monthly honorarium.

\section{Equity and Other Funds}

Capital for KVK comes from one-time deposits by SHGs (that may be taken back only if the SHGs withdraw from the federation) and grants received from DHAN. CDAs have a similar source of funds. In SPMS, an initial grant from the Ford Foundation and annual deposits from the SHGs constitute the capital. SVAWTC has equity from member cooperatives, and mandates that all its member cooperatives keep 5\% of their deposits with 
the federation. Grants from UNDP are the primary source of capital for SMMS and VOs receive one-time deposits from SHGs. Accumulated profits is a source of capital in all the federations.

\section{Income}

From April 2001, service charges paid by SHGs are the primary source of income for KVK. For the current year, it has been fixed as 10 percent of interest income of SHGs. Interest income is the major source of income for SPMS and SMMS. SPMS lends at 12 percent to VOs, who in turn lend it to SHGs at 18 percent. SPMS charges 18 percent on general loans and 15 percent on housing loans. Audit fee and interest are the major income sources for SVAWTC.

\subsection{Infrastructure and Systems}

\section{Infrastructure}

All four apex federations have their own offices; so do the CDAs in KVK and VOs in SMMS. SPMS has offices for its branches, and all the thrift cooperatives have offices in the villages. All apex federations have telephones. KVK and SPMS have computers, and SMMS provides vehicles (motorcycles) for its employees.

\section{Savings and Lending Process}

All payments SHG members make - savings, loan repayment, insurance premium, etc. - are made to SHGs during the weekly or monthly group meeting, even if some of these are to be transferred to the federation. Members do not receive or pay back loans directly from the federation or bank. Loans are issued during the regular meeting or in a specially convened meeting, when a loan from the bank or federation is received after the regular meeting day.

In SHGs, members request loans during the weekly/monthly group meeting. The group, based on the lending norms of the SHG and purpose of the requested loan, accepts the request if there is a consensus. If the requested loan is small or urgent, it is given out from the collections during the day after money for payment to the federation or the bank has been set apart. Larger loan applications are sent to the federation (CDA/VO), which decides on the request based on its lending criteria. In the thrift cooperatives, members submit loan applications to the cooperative after getting the signature of all members of the joint liability group, and the cooperative then decides on the loan during its monthly executive committee meeting.

\section{Accounting}

All the organizations - apex federations, VOs/CDAs, and SHGs maintain separate accounts. SHGs have part-time accountants who are paid a monthly fee. In KVK and SPMS, the fee is pooled at the CDAs / SPMS branch office, and the accountant(s) paid after 
their work is reviewed. Accounts of CDAs are maintained by KVK staff; an accountant handles the accounts of four to five CDAs. The CDAs pay a service charge to KVK for this service. SHGs and Village Organizations in SMMS hire accountants locally. All apex federations and all thrift cooperatives have fulltime accountants. In KVK, a certified external accountant audits the accounts of all the SHGs, CDAs, and the apex federation annually. SVAWTC also does the same, while SPMS does so only at the federation level. SMMS carries out an annual internal audit of the primary groups, while external auditors audit only funds received from UNDP.

\section{Resource Mobilization}

KVK and SPMS give more attention to resource mobilization than the other two federations. SMMS started out with a large capital grant from UNDP to be used for lending to the SHGs. SVAWTC does not receive any external funds. Programs for mobilizing fixed deposits and specific purpose savings have not been very successful in any of the federations (they are relatively more successful in SPMS).

KVK and SPMS take special efforts to mobilize resources both internally and from external sources. They organize periodic campaigns to motivate SHG members to increase their savings. The primary source of external resources in KVK is commercial banks under the SHG-Bank Linkage program, though recent loans (especially the housing loans) received by the apex federation has significantly increased its share in total SHG liabilities. Loans and grants under the SGSY program are a new source of funds for SHGs in KVK. In SPMS, the primary source of external funds is the federation, since SHGs have started receiving loans directly from banks only recently.

\section{Risk Management}

In the SHG and thrift cooperative federations, this task is performed at multiple levels. In the SHG federations, all the structures have their own lending norms that incorporate risk assessment. In addition to assessing the credit worthiness of their immediate borrower, the federations (apex as well as CDAs/VOs) also appraise some of the SHG member's loan applications for which the loan is being requested. The federations attribute this to limited capacity within most SHGs to carry out this assessment, and the increased diligence needed when external funds are involved.

In KVK, SHGs maintains a risk fund (equivalent to a loan loss reserve) from a fee on all loans issued. The SHGs pay a similar fee on the loans they receive from the CDAs, and the CDAs pay the same on the loans received from the apex federation. SHGs also pay a fee to CDAs on loans received from the banks; the reason cited was that the federation is responsible for ensuring the repayment of these loans although it does not guarantee them. CDAs lend the risk fund; SHGs hold them as a bank deposit. In SPMS, only the federation collects a risk fund. SVAWTC and the thrift cooperatives create a loan loss reserve from the annual profits.

None of the federations (and the SHGs and thrift cooperatives) maintain information on portfolio at risk. All of them instead collect information on monthly loan demand, payment, and default. The federations perceive the current systems of repayment 
monitoring and lending norms to be sufficient means of risk management, though they agree that its utilization needs further improvement.

\section{Repayment Monitoring}

All federations have a repayment monitoring system at all levels. All loans have a repayment schedule. The schedule is standardized in SMMS and SVAWTC. It is flexible members specify the schedule within the limits set by the lending norms - in KVK and SPMS. Payments are monitored, and actions such as penalties, stopping further loans, etc. are taken in case of delinquency. The federation provides support to SHGs that have repayment problems through special meetings conveyed by the staff and board members of federation, visits by officeholders of well-performing groups, personal counseling of individual member groups, etc. The loans are rescheduled when the default is perceived to be due to genuine reasons. KVK and SPMS have written lending policies that prescribe penalties for delinquency. However, adherence to the policies is not very rigid, and there is difficulty in getting all the SHGs to fully adopt the lending policy.

KVK, SPMS, and SMMS monitor repayment performance of loans by repayment rate, i.e. the percentage of current expected payments to actual payments. In any given period (month or quarter), overdue balance gets added to next period's expected loan repayment. SVAWTC calculates only the number and amounts of installments in default.

\section{Financial Management}

None of the federations have given adequate attention to financial management. This is partly because loan demand usually exceeds supply, and shortage of funds, rather than idle cash, is the main problem. Nonetheless, the federations that receive external funds have periods of surplus cash problem since cash flow from the external agencies is difficult to predict accurately. Given the large amounts of loans received by KVK and SPMS, even a small period during which the funds are idle causes significant financial losses. Even in the absence of external loan funds, insufficient attention to financial management might be causing loss of interest income in SVAWTC and SMMS because of funds remaining idle for periods between the members' repayment and issue of new loans.

\section{Review, Planning and Budgeting}

In KVK, the review and planning process is carried out in CDAs and the block federation. The SHG officeholders participate in the cluster level review and planning meetings, and plan for their respective SHGs. SMMS facilitates preparation of microinvestment plans at the SHG level. The preparation of the plans in the SHGs and its consolidation at the VO level is a prerequisite for utilization of the UNDP grant funds. SVAWTC and KVK prepare an annual budget. KVK, SMMS, and SVAWTC also prepare annual reports of their activities. SVAWTC also prints the annual report and makes it available to all member cooperatives and the public. 


\section{Annex 4. Profiles of the Promoter Agencies}

\section{Development of Humane Action (DHAN) Foundation, Madurai}

DHAN Foundation is a large NGO working on primarily on microfinance and irrigation management in rainfed-tanks. It implements projects in the three southern states of Tamil Nadu, Andhra Pradesh and Karnataka, and the union territory of Pondicherry. It has contributed to microfinance and irrigation policy at the national level, through its membership in expert committees and task forces. It was a member of the microfinance task force appointed by the Reserve Bank of India in 1998 to help define a national policy for microfinance. It regularly conducts capacity building workshops for NGOs and banks banks on SHG-Bank linkage. DHAN Foundation was promoted as a spin off organization from Professional Assistance for Development Action, a leading NGO, in 1998.

Society for Elimination of Rural Poverty (SERP), Hyderabad

SERP is an agency of the Government of Andhra Pradesh that was created primarily to implement projects for poverty eradication. The society is chaired by the Chief Minister and has other eminent members of society in its governing board. Among other projects, SERP implements the World Bank supported Andhra Pradesh District Poverty Initiatives Project and the Andhra Pradesh Rural Poverty Reduction Project. The two projects together implement activities in over 500 mandals spread over all districts in the state. The focus of both these projects is to make a significant improvement in the livelihoods of the poor.

Cooperative Development Foundation (CDF), Hyderabad

CDF, earlier known as Samakhya, is involved in promoting cooperatives, capacity building of cooperatives, and in advocacy work to free cooperatives from government control. It has promoted different types of cooperatives - multi-purpose, rice, seed, dairy, and thrift. Among the various cooperatives it has promoted, it has been most successful in thrift cooperatives. CDF was instrumental in getting a new cooperative law (Andhra Pradesh Mutually Aided Cooperatives Act - 1995) enacted. Similar Acts have since been enacted in seven more states. CDF also supports other NGOs in the promotion of cooperatives. 
Table 15. Microfinance Program of the Promoter Agencies, 2002

\begin{tabular}{lrrr}
\hline \multicolumn{1}{c}{ Particulars } & DHAN & SERP & CDF \\
\hline Clientele & & & \\
Members & 164,552 & 67,226 & 87,500 \\
Primary Groups & 10,544 & 5000 & 400 \\
Average membership in primary & 16 & 13 & 219 \\
$\quad$ group & & & \\
$\quad$ Apex federations & 32 & 20 & 41 \\
Savings & & & \\
$\quad$ Savings (million) & 283 & 84 & 192 \\
Average Savings & 1,720 & 1250 & 2,194 \\
$\quad$ Reserves and surplus (million) & 81 & 12 & 47 \\
Loans (million) & & & None \\
$\quad$ External loans to date & 520 & 52 & n.a. \\
$\quad$ Total credit generated & 1,010 & 794 & 180 \\
$\quad$ Loan portfolio in primary groups & 552 & n.a. & \\
\hline n.a.: Not Available & & & \\
Notes: Data for SERP for 2000 $\quad$ Currency in Rupees & & & \\
$\quad$ & & &
\end{tabular}




\section{Annex 5. Individuals Interviewed}

\section{Federations:}

1. Governing Board members and Staff team, Community Development Society, Alappuzha

2. Governing Board members and Staff team, Community Development Society, Malappuram

3. Governing Board members and staff team, Kurinji Vattara Kalanjium, Alanganallur, Tamil Nadu

4. Governing Board members and Staff team, Sanghamitra Mandal Mahila Samakhya, Hindupur, Andhra Pradesh

5. Governing Board members and Staff team, Sri Padmavathy Abyudaya Sangham, Tirupati, Andhra Pradesh

6. Governing Board members and Staff team, Sri Viswabharati Association of Women's Thrift Cooperatives, Warangal, Andhra Pradesh

7. Governing Board members and Staff team, Association of Men's Thrift Cooperatives, Warangal, Andhra Pradesh

\section{Promoter Agencies:}

1. Ms. Jaya Arunachalam, President, Working Women's Forum, Chennai

2. Mr. K.T. Jose, Chief Executive, Kudumbasree Program, Trivandrum, Kerala

3. Mr. Narendar, Program Leader, Development of Humane Action Foundation, Madurai

4. Mr.Vijay Mahajan, Executive Director, Basix, Hyderabad

5. Mr. K. Raju, Chief Executive, Society for Elimination of Rural Poverty, Hyderabad

6. Ms.Vidya Ramachandran, Mysore Resettlement and Development Agency, Bangalore

7. Mr. Rama Reddy, President, Cooperative Development Foundation, Hyderabad

\section{Others:}

1. Mr. Bikram Duggal, ICICI, Mumbai

2. Mr. R. Prabha, Deputy General Manager, Canara Bank, Bangalore

3. Mr. Ramachandran Nair, Deputy General Manager, NABARD, Mumbai

4. Mr. C.S. Reddy, Chief Executive, APMAS, Hyderabad

5. Mr. K.M. Thiagarajan, Advisor - Microfinance, ICICI (Ex-Chairman, Bank of Madurai) 


\section{References}

APMAS (Andhra Pradesh Mahila Abhivrudhi Society). http://www.apmas.org Accessed on $07 / 22 / 2003$

APMAS. 2003. Designing Secondary Institutions of SHGs (engaged in savings and credit services). Paper for discussion at the National Workshop on SHG federations, June 20-21, 2003. Hyderabad, India

Bowman. 1995. "Rotating and Accumulating Savings and Credit Associations: A

Development Perspective.” World Development 23(3):371-384

CDF (Cooperative Development Foundation). 1997. Member Participation rates in New Generation Thrift Cooperatives around W arangal Town in Andhra Pradesh. Hyderabad, India

Eschborn, Renee Chao-Beroff. 1999. Self Reliant Village Banks, Mali (Case Study). CGAP. Washington, DC.

FWWB (Federation of World Women Banking). 2002. Indian Self Help Groups and Banlgadesh Grameen Bank Groups: a Comparative Analysis. Ahmedabad, India

FWWB (Federation of World Women Banking). 1997. India's emerging SHG Federations. Ahmedabad, India

GCMMF (Gujarat Cooperative Milk Marketing Federation). http://www.amul.com Accessed on $07 / 17 / 20003$

Harper, Malcom. 1998. The New Middlewomen, Profitable Banking through on-lending groups. Oxford/IBH. New Delhi, ITDG Publications. London.

Harper, Malcom. 2002. The Promotion of Self Help Groups. NABARD, Mumbai, India.

Kropp, Erhard W. and B.S.Suran. 2002. Linking Banks and (Financial) Self Help Groups in India - An Assessment. Paper presented at the Seminar on SHG-Bank Linkage Programme. New Delhi, India.

MYRADA (Mysore Resettlement and Development Agency). n.d. Community Based Resource Centres: A Study Report. Processed

NABARD (National Bank for Agriculture and Rural Development). http://www.nabard.org Accessed on 07/17/2003

NABARD. n.d. Ten Years of SHG-Bank Linkage. Mumbai, India.

Puhazhendhi.V. 2000. Evaluation Study of Self Help Groups. NABARD, Mumbai. 
Reserve Bank of India (RBI). 1999. Task force on supportive policy and regulatory framework for microfinance in India. Mumbai, India

Sa-dhan. n.d. Report of National Workshop. Strengthening Access to Financial Services for the Poor: Role of Community Based Organizations. Accessed from http://www.sa-dhan.org on 07/30/200

SEWA (Self Employed Women's Association). n.d. Annual Report 2001. Accessed from http://www.sewa.org/ on 08/04/2003

SIFFS (South Indian Federation of Fishermen Societies). http://www.siffs.org Accessed on $07 / 17 / 2003$

Tankha, Ajay. 2002. Self-help Groups as Financial Intermediaries in India: Cost of Promotion, Sustainability, and Impact. A Study prepared for ICCO and Cordaid. The Netherlands.

UNDP-World Bank Water and Sanitation Program. n.d. Credit Connections: Sri Padmavathy Mabila Abyudaya Sangam. Accessed from http://www.wsp.org/pdfs/sa creditsripad.pdf

WOCCU (World Council of Credit Unions). http://www.woccu.org Accessed on $07 / 17 / 2003$

World Bank. 2000. Andhra Pradesh District Poverty Initiatives Project. Project Appraisal Document. Washington, DC. Processed.

World Bank. 2003. Microfinance in India: Issues, Constraints, and Potential for Sustainable Growth. Washington, DC.

World Bank. 2003. Andhra Pradesh Rural Poverty Reduction Project. Project Appraisal Document. Washington, DC. Processed. 